\title{
The Clinical Significance of the Positive Surgical Margin in Oral Cancer
}

\author{
A Thesis submitted to the Faculty of Graduate Studies \\ of \\ The University of Manitoba \\ In partial fulfilment of the requirements of the degree \\ of \\ Master OF Surgery
}

\section{Department of Surgery \\ University of Manitoba}

Winnipeg

Copyright $\odot 2006$ by Abdulaziz Binahmed 
THE UNIVERSITY OF MANITOBA

\section{FACULTY OF GRADUATE STUDIES \\ $\therefore \div \div \div \div$}

COPYRIGHT PERMISSION

The Clinical Significance of the Positive Surgical

Margin in Oral Cancer

BY

Abdulaziz Binahmed

A Thesis/Practicum submitted to the Faculty of Graduate Studies of The University of Manitoba in partial fulfillment of the requirement of the degree

OF

MASTER OF SCIENCE

Abdulaziz Binahmed @ 2006

Permission has been granted to the Library of the University of Manitoba to lend or sell copies of this thesis/practicum, to the National Library of Canada to microfilm this thesis and to lend or sell copies of the film, and to University Microfilms Inc. to publish an abstract of this thesis/practicum.

This reproduction or copy of this thesis has been made available by authority of the copyright owner solely for the purpose of private study and research, and may only be reproduced and copied as permitted by copyright laws or with express written authorization from the copyright owner. 


\begin{abstract}
Purpose: This study examines the significance of the positive surgical margin.

Materials and Methods: An historical cohort of 425 patients from the cancer registry of the Province of Manitoba with squamous cell carcinoma of the oral cavity treated with surgery \pm radiotherapy was examined.

Results: The mean age of the cohort were 63 years, and $58.8 \%$ were males. Seventy-two percent of tumors involved the tongue and floor of mouth, and $43 \%$ of patients presented with Stage III and IV disease. The 5-year survival was $62 \%$. Survival was related to age, T-Stage, and N-Stage. Patients with clear margins had a survival rate of $69 \%$ when compared to those with close $58 \%$, and involved margins $38 \%$. After controlling for the other significant prognostic factors, involved surgical margins increased the risk of death at 5 years by $90 \%$.

Conclusions: The status of the surgical margin is a powerful predictor of outcome.
\end{abstract}




\section{Acknowledgment}

To My Advisory Committee.

Dr. R.W. Nason

Dr. A Abdoh

Dr. H. Unruh

To Cancer Care Manitoba Medical Record Staff.

Twylla Versluis

Heather Whittaker 


\section{Dedication}

This work is dedicated to my wife Munira,

For her Patience, Sacrifice, and Support during the past and the upcoming years, My daughter Haya who is a source of joy and inspiration,

My Parents for there continues support 


\section{Table of Contents:}

I. INTRODUCTION

II. LITERUTURE REVIEW

i. Epidemiology

ii. Etiology

iii. Clinical Staging

vi. Prognosis of Oral Cancer

III. MATERIALS AND METHODS

IV. RESULTS

V. DISCUSSION

VI. TABLES

VII. FIGURES

VIII. REFERENCES 


\section{$\underline{\text { List of Tables }}$}

Table 1. Baseline Characteristics.

Table 2. 5-year Overall Survival Probabilities by Major Demographic and Clinical Variables.

Table 3. Cox's Proportional Hazard Model Predicting 5-year Overall Survival. 


\section{List of Figures:}

Figure 1. 5-Year Overall Survival.

Figure 2. 5-Year Disease Specific Survival.

Figure 3. 5-Year Disease Free Survival.

Figure 4. 5-Year Overall Survival By Gender.

Figure 5. 5-Year Overall Survival By Age.

Figure 6. 5-Year Overall Survival By Site.

Figure 7. 5-Year Overall Survival By Treatment.

Figure 8. 5-Year Overall Survival By Stage.

Figure 9. 5-Year Overall Survival By T-Stage.

Figure 10. 5-Year Overall Survival By N-Stage

Figure 11. 5-Year Overall Survival By Margin.

Figure 12. Estimated 5-Year Survival Pattern By Surgical Margin For Age $<65$ Years.

Figure 13. Estimated 5-Year Survival Pattern By Surgical Margin For Age $65+$ Years. 


\section{INTRODUCTION}

Malignant neoplasms are a major cause of fear, morbidity and mortality all over the world. Cancer is one of the five main causes of death in all societies. Cancer of the oral cavity represents approximately $3-5 \%$ of all cancers diagnosed yearly in the United States and Canada $(1,2)$. Each year there are 27000 newly diagnosed cases in the United States and 3200 newly diagnosed oral cancers in Canada $(1,2)$. In Canada the estimated deaths from oral cancer cases is 1050 cases for the year 2005(2).

The oral cavity is that part of the upper aerodigestive tract which extends from the mucocutaneous junction at the vermillion border of the lip to the anterior surface of the faucial arch. It is lined by squamous epithelium containing interspersed minor salivary glands and it also contains dental alveolar structures that support the upper and lower dentition. Primary tumors of the oral cavity may arise from the surface epithelium, minor salivary glands or submucous soft tissue as well as from dental structure, bone or neurovascular tissue. Squamous cell carcinoma of the oral cavity forms more than $90 \%$ of all newly diagnosed cases of oral cancer $(3,4)$. The majority of the patients with oral cancer are males. A rising incidence has been observed in females over the past 50 years (5). Anatomical sites in the oral cavity that have been described by the International Union Against Cancer (UICC)/ American Joint Committee on Cancer (AJCC) (6.7) Staging System are the tongue, floor of mouth, gingiva, buccal mucosa, retromolar trigone and hard palate. The tongue and the floor of mouth are the most common sites of origin for primary squamous cell carcinoma in the oral cavity in the Western World. In other parts of the world e.g. Middle east and Asia, the retromolar trigone and buccal 
mucosa are the most frequently encountered primary sites due to tobacco chewing and the chewing of betel nuts. Despite controversy and debate during the last century between different health care regarding the best treatment of oral cancer using radiation, surgery or chemotherapy, surgery still plays a primary role in the control of the disease.

There is no consensus as to how much normal tissue should be removed around a tumour in order to reduce the risk of local recurrence. Galen two millenia ago suggested that when excising a malignant tumour one should "make an accurate incision surrounding the whole tumour so as not to leave a single root"(8). Now we are a little wiser in that it is widely accepted by head and neck surgeons that inadequate excision of a tumour leads to early primary site recurrence. Reports suggest that approximately $75 \%$ of patients with a positive resection margin will either develop a local recurrence or demonstrate a residual tumour upon re-operation (9-12).

In analyzing this historical cohort of oral cancer patients we divided the patients into three different groups. The first group had a clear surgical margin defined as $>2 \mathrm{~mm}$ of normal tissue around the tumor. The second group had a close surgical margin defined as $<2 \mathrm{~mm}$ of normal tissue around the tumor. The third group has a positive surgical margin with invasive squamous cell carcinoma at the margin.

The objective of this study was to examine the overall survival and the local control between these three different groups. 


\section{LITERETURE REVIEW}

\section{i. Epidemiology}

Oral cavity cancers account for about $3 \%$ of all cancers diagnosed each year in north America. This is estimated to be 27,000 newly diagnosed cases in the United States and 3,200 cases in Canada. Slightly more than 10,000 Americans and 1,000 Canadians will die of oral cancer each year $(1,2)$. Studies from around the globe show that for both sexes combined cancer of the mouth and pharynx ranks sixth overall behind lung, stomach, breast, colon and rectum and cervix uteri in that order (13). The rates range from a low of $1.8 / 100,000$ per year to a high of $47 / 100,000$ per year (14). The highest rates of oral cancer in the world are found in France (15), the Indian subcontinent, Brazil (16) and central/eastern Europe. There are also marked differences between countries in the same geographic regions $(17,18)$.

The incidence of oral cancer increases with age in all parts of the world. In the West, $98 \%$ of the patients are over 40 years of age. In the high prevalence areas of the world many of the patients are less than 35-years-old owing to heavy usage of various forms of tobacco. Furthermore it is now clear that in many Western countries there has been during the past two or three decades an alarming rise in the incidence of oral cancer particularly among younger men a trend that appears to be continuing (19).

In industrialized countries men are affected two to three times as often as women. The most important risk factors are alcohol and tobacco consumption for intraoral cancer and sun exposure for lip cancer in those who work outdoors. The incidence of tongue and other intraoral cancer for woman can be greater or equal to that of men in high incidence areas such as India where chewing tobacco is also common among women (20). There has been a gradual increase of the number of female patients reflected by the change in 
male to female ratio in the Western societies. In 1996 Oliver et al (21) reported a review of 92 cases of oral squamous cell carcinoma from 1985 - 1992 and found the male to female ratio of 1.5:1. 


\section{ii. Etiology}

\section{$\underline{\text { Tobacco }}$}

There is absolutely no doubt that on a global scale the use and abuse of tobacco products is the major cause of oral cancer. Typically $90 \%$ of men and $60 \%$ of women with oral carcinomas use tobacco $(22,23,24)$. The incidence rate of oral carcinoma in smokers is six to ten times greater when compared to non-smokers. (25)

There is strong evidence that active smoking is related to oral cancers. The most comprehensive source of evidence remains the International Agency for Research on Cancer (26). This evidence is also summarized by the US Surgeon General's report of 1989. The attributable risk for oral cancer was the highest in males at $92 \%$. Some literature suggest that pipe and cigars are less risky for oral cancer than cigarettes (27) but a very extensive study from northern Italy shows higher risks associated with these practices for cancer of the mouth and esophagus than with cigarettes (28). In Scandinavia and North American snuff has been the source of controversies for several years now. Brown et al (29) describe snuff dipper's cancer in the south eastern United States where the habit of placing snuff in the lower labial sulcus was common. Indeed this was the basis of the classical description of verrocus carcinoma by Akermann as long ago as 1948(30) and confirmed by McCoy and Waldron much later (31). A study based on combined data of the 1986 US National Mortality Follow Back Survey and the coincident National Health Interview Survey conclude that the use of smokeless tobacco either as a snuff or chewing tobacco does not increase the risk of oral cancer or of cancer of the digestive organs (32). In Scandinavia it is now becoming clear that local snuff is 
not a major risk factor for oral cancer. Two recent case control studies of the oral cancer cases in Sweden have failed to show an association $(33,34)$.

Betel quid is a completely different form of smokeless tobacco. It is prepared from areca nut cured or sun dried and chopped. These pieces are placed on a leaf of the Piper betel vine and slaked lime is an essential ingredient that is added to the combination to lower the $\mathrm{pH}$ and accelerate the release of alkaloid from both tobacco and nut. It is a very common practice in India, Sri Lanka and Pakistan, Bangladesh, Thailand, Cambodia, Malaysian, Singapore, Indonesia, Philippine, Taiwan and China. The carcinogenicity of the betel quad mixture has been clearly established in meta-analysis of 17 published studies by Thomas and Wilson (35). Gupta Et al (36) followed up 30,000 individuals over a ten-year period in three areas of India. The annual adjusted incidence of oral cancer was 23 to 100,000 among betel quad tobacco chewers compared with zero in smokers and non-chewers.

\section{Alcohol}

It is very difficult to separate the effects of alcohol and tobacco as most heavy alcohol consumers also use tobacco. Nevertheless some cohort and case control studies have found an increased risk of upper aerodigestive tract cancer associated with alcohol drinking in non-smokers (37). The epidemiological evidence shows that all of alcoholic drinks are dangerous if heavily consumed (38). Boffetta et al (39) has shown that the carcinogenic effect of tobacco and alcohol is through direct contact and tends to be site specific in the oral cavity. Tobacco smoking was more closely associated with carcinoma of the soft palate and alcohol was more closely associated with carcinoma of the floor of mouth and tongue. 
There are several ways in which alcohol is thought to contribute to head and neck cancer by both local and systemic mechanism. The most prominent one is that ethanol increases the permeability of oral mucosa to water itself and to many water-soluble molecules including important carcinogens. The other way that alcohol can contribute to head and neck cancer is through the immediate metabolite of ethanol, acetaldehyde, which has the capability of damaging the cells. Alcoholic liver disease is common in heavy drinkers and this reduces the detoxification of active carcinogens. Alcohol is also high in calories, which can suppress appetite in heavy drinkers and causes malnutrition, which may contribute to oral cancer.

\section{Nutritional Deficiencies}

Nutritional deficiencies have been associated with oral cavity carcinoma. The original papers that were published in 1919 showed a significant relation between iron deficiency and increased incidence of upper GI tract cancer in middle-aged women suffering from chronic anemia. Several animal studies have shown that there is an epithelial cell kinetic change with iron deficiency. Some of the studies have shown an increase of turnover (40) that theoretically increases the risk of mutational error and other shows decrease (41). Both studies have shown the result of an epithelial atrophy and increased cancer risk.

Eleven of thirteen case control studies that have examined association between fruit and vegetable consumption and oropharyngeal cancer report a meaningful inverse association (42-46). 


\section{Viruses}

The knowledge of viruses as a human carcinogen has improved in the past two to three decades. Viruses contribute to the multi-step process of carcinogenesis in many human neoplasms. Human papilloma virus, especially human papilloma 16 , is the most common type associated with both cervical and oral cancer (47-49). In vitro studies show that high-risk HBV types can immortalize primary human oral epithelial cells. However, exposure to tobacco related chemicals were required for these cells to progress to a fully malignant phenotype $(50,51)$. 


\section{iii. Clinical Staging}

In the '40s Dr. Pierre Denoix at the Institute Gustaveroussy in France developed the TNM system. Subsequently the International Union Against Cancer established a special committee on clinical stage classification under his leadership and continued to develop the TNM classification. At the same time the American Joint Committee for Staging was organized in 1959 for the purpose of developing a system of clinical staging of cancer. Both organizations joined together in 1988 and agreed upon the TNM classification system that was published at that time. This system has had multiple modifications and changes since then. The most recent system was published in 2003. The TNM system reflects the anatomical extend of the tumor. The staging of the primary site (T-stage) emphasis the size or surface dimension of the tumor. A recognized deficiency of this system is omission of tumor thickness or depth of infiltration. The $\mathrm{N}$ staging system for regional cervical lymph nodes is uniform for all epithelial tumors of the upper aerodigestive tract. The nodal staging system takes into account the size, multiplicity, and location of metastatic nodes. As determined by clinical exam and imaging studies, the presence or absence of distant metastasis is documented as M0 or M1 by routine work up that usually includes a chest radiographs and routine blood chemistries. 


\section{iv Prognosis of Oral Cancer}

Despite the improvements in surgical and radiotherapeutic technique intraoral squamous cell carcinoma has a relatively unfavourable prognosis with an overall fiveyear survival rate of $35-50 \%$. The survival rate has regrettably remained virtually unchanged over the past three decades. The increase in the incidence of oral cancer accentuates this mortality from the cancer.

Several parameters have been adapted and applied by clinicians to evaluate the prognosis of oral cancer. These parameters can be divided into epidemiological parameters which include the age, sex, race, alcohol and tobacco intake and comorbidity; clinical parameters which include the TNM classification and stage and the site of the primary tumor; and histological parameters which include the marginal status, the perineural or perivascular invasion, histopathological grading and tumor thickness and extracapsular spread. 


\section{Epidemiological Factors}

An epidemiological study by Marques et al (53) concluded that there was a significant increase in local recurrence in patients over 80 years of age and that there was a higher incidence of regional recurrence in men than in women. They also reported the worst prognosis for heavy smokers compared to non-smokers but found no significant differences between alcohol users and non-alcohol users. Funk in 2002(54) reported the National Cancer Data Base report on Head Neck data from 1985 - 1996 and he found that the five-year relative survival was higher in younger patients compared to older patients. He also found that African-American had a worse prognosis than other racial

groups. His data also showed that for all stages combined men had a significantly worse five-year relative survival than women. Franco (55) in 1993 showed that numerous factors including behavior differences between males and females, contribute to higher compliance for treatment among females and to the better reported survival.

Comorbidities have been evaluated using different indexes. Kaplan-Feinstein Index (56), Charlson Comorbidity Index (57), and National Cancer Institute of Aging Index (58). Piccirillo (59) has modified the Kaplan-Feinstein Index into the Adult Comorbidity Evaluation 27 Test designed for patients with head and neck cancer. Several authors have described the prognostic importance of comorbidities in different scoring systems on the survival of surgically treated oncological patients. Borggreven et al (60) reported a statistically significant lower survival rate in patients with severe comorbidity compared to patients with mild or moderate comorbidities, $29 \%$ versus $64 \%$ respectively. 


\section{Clinical Prognostic Factors}

The single most important factor affecting long-term results after treatment of carcinoma of the oral cavity is the stage of the disease at the time of presentation. For early stage tumors excellent cure rate is achieved. The five year survival rate for patients with oral cancer treated at Memorial Sloan-Kettering Cancer Center between 1986 and 1995 showed that for Stage I oral cancer the five year disease-specific survival was more than $90 \%$ while for Stage II -IV $80 \%, 65 \%, 55 \%$, respectively. The overall survival in the same center was site dependent; with tumors in the buccal mucosa and retromolar trigone having the worst outcome (61).

Magnano et al $(62,63)$ found that the $\mathrm{T}$ stage was a consistent and dependent predictor of pathologically involved cervical lymph nodes. In addition, maximal tumor diameter has been shown to predict local recurrence in tumors arising from the lower lip, oral cavity and oropharynx. Pernot in 1996 reported on 565 patients in which he showed that the five-year survival for patients with $\mathrm{T} 1$ lesion was $70 \%$ compared to $29 \%$ in patients with T3 disease (64).

It is not surprising that the presence of clinically positive lymph nodes at the time of presentation is probably the single most important factor in determining outcome and prognosis. In general patients presenting with neck node metastases do half as well as patients who present with a primary tumor only. Jones et al (65) performed a univariate and multivariate analysis of a number of tumor factors and prognosis in oral cancer on 524 patients. Their study showed that only the $\mathrm{T}$ stage and the $\mathrm{N}$ stage were significant as predictors for survival. 
Mamelle et al (66) reviewed 914 patients and his multivariate analysis showed that the number of positive nodes was a significant and independent predictor of survival.

Olsen et al (67) has shown that the number of positive lymph nodes reflects the prognosis and overall survival in 284 patients that he studied. This information is in agreement with a study that Shah (68) performed on 704 patients showing that the failure rate was significantly higher as the number of positive nodes increased. 


\section{Histological Prognostic Factor}

\section{Tumor Thickness}

In the last two decades there has been growing evidence in the literature that tumor thickness is a reliable indicator for predicting both regional node involvement and survival in oral squamous cell carcinoma. There is substantial agreement among authors despite the lack of comparable study groups, measurement technique, and cut off values. This paradoxically seems to re-enforce its reliability.

Breslow (69) has clearly shown that prognosis in cutaneous melanoma correlates with the thickness of the tumor. The same principal has been applied to squamous cell carcinoma of the oral cavity. Spiro et al (70) studied 105 patients with squamous cell carcinoma of the oral tongue and floor of mouth and found that if the tumor thickness was greater than $2 \mathrm{~mm}, 38 \%$ of the patients showed lymph node metastases while in the group where the thickness was less than $2 \mathrm{~mm} 7.5 \%$ had lymph node metastases. Brown et al (71) examined the data of 87 patients with a primary tumor of the tongue and floor of mouth. Univariate and multivariate statistical analysis revealed that tumor thickness greater than $3 \mathrm{~mm}$ was a significant parameter for better survival and not for regional recurrence. A more recent study done by O'Brien and his colleagues in 2003, studying a total of 145 patients with Stage T1 or T2 oral cavity squamous cell carcinoma, has shown that the prognosis changes significantly when the tumor thickness is greater than $4 \mathrm{~mm}$. Local control, cervical node involvement, and survival rates of $91 \%, 8 \%$, and $100 \%$ respectively for tumors less than $4 \mathrm{~mm}$ were demonstrated. This is compared to $84 \%$, $48 \%$, and $74 \%$ for those tumors with a thickness of $4 \mathrm{~mm}$ or more $(\mathrm{p}<0.01)$. In their 
conclusion they emphasized the need to standardize the techniques of measurement of tumor thickness to allow a multi-institutional study to be carried out (72). 


\section{Perineural Invasion}

Perineural invasion by squamous cell carcinoma is more common than previously thought and is an ominous sign that correlates with an increased incidence of local recurrence, regional lymph node metastasis, and decreased survival. In the literature the occurrence of perineural invasion from carcinoma of the head and neck is reported to range from $6-30 \%(71,73-76)$. Lydiatt et al (74) in a retrospective study of 156 patients with a squamous cell carcinoma of the tongue reported that perineural invasion significantly and adversely affected survival of patients: $63 \%$ versus $88 \%$ for patients that did not show perineural invasion. Fagan et al (75) in a study of 142 patients with carcinoma of the larynx, hypopharynx, oral cavity and oropharynx showed that there was a significant increase in mortality rates in patients that have perineural invasion (54\%) compared to those without perineural invasion $(25 \%)$. He also found that local recurrence occurred more frequently in patients with perineural invasion.

Soo et al (76) and Brown et al (71) found significant correlation between perineural invasion and regional recurrence in oral cancer. Rahima et al (73) in his study found that the five year disease-specific survival rate for patients with and without perineural invasion were $56.6 \%$ and $94.6 \%$ respectively with a $\mathbf{P}$ value less than 0.0001 . 


\section{Extracapsular Spread}

Cervical lymph node metastases are a major adverse determinant of clinical behavior. The prognosis, however, is even more ominous when the nodal metastases has extended beyond the capsule of the lymph node into the adjacent perinodal soft tissue. About $40-70 \%$ of patients with histologically positive cervical lymph node will demonstrate extracapsular spread. The frequency varies somewhat with the size of the lymph node. Extracapsular spread is seen in $15-25 \%$ of lymph nodes up to $1 \mathrm{~cm}$ in sizes and is $75 \%$ of those in excess of $3 \mathrm{~cm}(77-80)$. Patients with extracapsular spread have a shorter disease free interval and are at greater risk for regional recurrence and distant metastases. Perivascular and perineural infiltration by extranodal tumor as well as the presence of tumor emboli and invasion of regional lymphatics have an adverse impact on prognosis (81). 


\section{$\underline{\text { Surgical Margins }}$}

There is no consensus as to how much normal tissue should be removed around the tumor in order to reduce the risk of local recurrence and improved survival. Galen suggested that "when excising a malignant tumor one should make accurate incisions surrounding the tumor so as not to leave a single root" (8). This statement two millennia ago is now one of the basic principles of oncological surgery. If a cure is to be expected for localized cancer, complete excision must be performed with adequate resection margins.

There is little doubt that a gross residual tumor will effect local control and nearly always increase mortality. Analysis of the literature shows that there is a lack of standardization and precision in defining what is a positive margin, a close margin and a clear margin. There is no prospective controlled study evaluating the effect of positive margins on local recurrence and overall disease free survival.

Data indicates that about $15-30 \%(9,82,83)$ of all oral carcinoma are inadequately excised. Some have claimed that the microscopic accuracy of inadequate surgical margin is at least $50 \%$ as judged by local recurrence. This false negative assessment is partially because of pathological and surgical difficulties with evaluation of preoperatively irradiated tissue and submucosal extension or skip areas. Another important factor is the miscommunication and lack of close cooperation between surgeons and pathologists as reported by Batsakis (83). 


\section{Definitions}

The definition of positive close and negative surgical margin lacks standardization and certainly precision. In a recent study by Meier (84) a custom designed questionnaire was mailed to members of the American Head \& Neck Society. A total of 1500 surveys were mailed and a total of 476 completed surveys were received. In the definition of clear margin $46 \%$ defined a clear margin as more than $5 \mathrm{~mm}$ on microscopic examination from the edge of the tumor on permanent section. The second most common response given was that the margin varied according to the clinical situation or that multiple criteria were used. Twelve percent reported that a clear margin was a margin that did not have an ink stain on the tumor edge. Participants were also asked what they considered to be a close margin: $69 \%$ defined close as a margin within $5 \mathrm{~mm}$ of the tumor on microscopic examination; $21 \%$ defined a closed margin as less than one high powered field; and $9 \%$ defined the closed margin with other criteria. When the surgeons were asked if they considered carcinoma in situ or dysplasia at the margin as a positive margin, $83 \%$ considered carcinoma in situ as a positive margin while $76 \%$ considered dysplasia as not a positive margin. This study definitely describes the lack of standardization in definition of the margin status.

Loree and Strong(82) describe surgical margin as being positive according to the following criteria. 1)close within $0.5 \mathrm{~cm}, 2$ ) dysplasia at the margin, 3) carcinoma in situ carcinoma at the margin, and 4) invasive carcinoma at the margin. Spiro et al(87) studied 150 previously untreated patients who underwent surgery for squamous cell carcinoma of the tongue. They found a significant increase in local recurrence in tumors with positive 
margins, which they define as invasive carcinoma at the margin. They defined close margins as within one high-powered field. Jacob (85) in 1993 defined a positive margin as being only those margins with invasive tumor at the margin. McMahon et al (86) defined clear margins as a margin within $5 \mathrm{~mm}$ from the nearest surgical margin, close margin as a margin between $1-5 \mathrm{~mm}$ of the surgical margin, and involved margin as a margin within $1 \mathrm{~mm}$ of the surgical margin.

What constitutes a close margin is also controversial as we can see in the previous paragraph. Different authors use different definitions. The definition of less than $5 \mathrm{~mm}$ from the invasive tumor has been widely used since the publication of Loree and Strong (82). Other authorities have described margins as close but uninvolved at a lesser distance. $(87,88)$. Yuen $(89,90)$ in his extensive studies on squamous cell carcinoma of the tongue reported a close margin to be a margin of less than $2 \mathrm{~mm}$. He also commented that the distance of histological resection margin couldn't be accurately measured unless a whole organ serial sectioning method is employed. 


\section{Post Removal Changes}

From in situ measurements by the surgeon to the final measurement on the microscope slide by the pathologist, oral cavity margins shrink from $30-50 \%$.

Beaumont et al (91) reported on his study on anterior oral squamous cell carcinoma significant changes in the longitudinal diameter of the whole specimen from in situ to first stage and also from fresh to fixed state. The most significant alteration was in the measured diameter of the tumor with a mean shrinkage of $4.28 \mathrm{~mm}$ from the fresh to the fixed state. In his study there was a reduction of $46 \%$ from the planned surgical margin before resection to the assessed measurement of microscopic clearance in the surgical pathology laboratory. Johnson et al (92) in 1996 did a study on mongrel dogs oral mucosa. He showed shrinkage rate in the labial buccal mucosa of $47.3 \%$ while the tongue shrinkage rate varied between $30.7 \%$ for the mucosal margin and $34.5 \%$ for the deep tongue margin. He also mentioned that the greatest proportion of shrinkage occurred immediately upon resection.

\section{Frozen Section}

Intraoperative frozen section analysis of margins is widely employed to assist in complete tumor resection. The technique of frozen section preparation dates to 1818 and has been credited to the work of Deremier (93). It has improved over the years. The accuracy of frozen section diagnosis compared with permanent control in head and neck surgery has consistently been reported between $95 \%$ and $99 \%$.

Several publications have assessed the accuracy of frozen section margins relative to the adequacy of tumor resection through measurements of local control and disease free survival. Byers et al (10) reviewed a selected group of 216 patients undergoing 
surgical treatment of squamous cell carcinoma of the head and neck. Twenty-three percent of his sample size then underwent an intraoperative margin revision due to a positive frozen section study. The local recurrence rate for free margin was $14 \%$, revised margin was $20 \%$, and for the positive margin $80 \%$. In his study he supports the use of frozen section margin evaluation in all cases of squamous cell carcinoma of the head and neck except T4 lesions. He reported that there is a poor local control rate in these tumors despite the margin status. Ord (94) in his study of 49 patients with oral squamous cell carcinoma noted an accuracy rate for frozen section margins of 99\% compared with permanent section of the same tissue. However, $70 \%$ of patients with positive final margin on the resection specimen were not detected by frozen section evaluation. Positive final margin included resection margins containing dysplasia, carcinoma in situ, infiltrating carcinoma and margins within $5 \mathrm{~mm}$ of the carcinoma. Two forms of error that can occur in frozen section margin evaluation. The first one is interpretive and the second is the sampling. Interpretive error denotes a failure to correctly identify the tissue present on frozen section slides. The sampling error is mainly related to the surgeon sampling a non-representative tissue and this has been reported to be mainly at the deep margin. New techniques need to be employed to advance the sampling and intraoperative assessment of the deep margin of squamous cell carcinoma of the oral cavity. 


\section{Margin and Prognosis}

Looser et al (11) retrospectively evaluated the charts of 1775 patients with epidermoid cancer of the head and neck treated surgically. Resection margins in 62 patients were reported to be positive. Seventy-one percent of the positive margin patients developed a local recurrence and only $19 \%$ were cancer-free. When he compared this group to the group of patients with negative margins $31 \%$ had local recurrence. The author concludes that a positive margin leads to a higher local recurrence rate at the primary site.

Zieske et al (95) studied 31 patients with microinvasive carcinoma at the margin. Ninety-four percent of these patients were Stage III and IV disease. The local failure rate was $29 \%$ and the three year survival was only $6.4 \%$ compared with the rates with negative margins of $6.6 \%$ and $59 \%$ respectively. Postoperative radiotherapy was employed in 25 patients of whom $28 \%$ had local failure, $60 \%$ had local regional failure and $84 \%$ were dead of disease at three years. The authors concluded that adjuvant postoperative radiotherapy was not effective in control of local disease in the presence of positive margins.

In a study of 270 patients with tumors from a variety of oral cavity, pharyngeal and laryngeal sites Chen et al (12) found the local recurrence rate in patients with negative margins to be $17 \%$. For the 35 patients with positive margins in this study the local recurrence rate for microinvasive carcinoma, in situ, and close margin were $55 \%$, $50 \%$ and $45 \%$ respectively. The proportion of patients surviving five years was significantly greater among those with negative margins. 
Loree and Strong (82) analyzed the significance of positive margins on survival in a large group of patients with a primary oral cavity carcinoma. A total of 398 patients were studied. The overall local recurrence rate in the entire positive margin group was twice the negative margin group, $36 \%$ versus $18 \%$ respectively. Positive margin also adversely affects survival. The five-year survival rate of the positive and negative margin groups were $52.7 \%$ and $60 \%$ respectively. In this study there was no improvement in overall survival or local control with the use of adjuvant radiotherapy.

In a study done on 50 glossectomy specimens done by Yuen et al (90) $16 \%$ of the patients developed a local recurrence. The local recurrence rate was higher with a close histological resection margin of less than $2 \mathrm{~mm}$. On a multivariate analysis perineural infiltration was found to be the only significant risk factor for local recurrence. The local recurrence rate was $4 \%$ without perineural infiltration and increased to $30 \%$ with the presence of perineural infiltration. He recommended a minimum of $1.5 \mathrm{~cm}$ surgical resection margin in resecting a squamous cell carcinoma of the oral tongue.

In a recent study by Sutton et al (96) from the Department of Maxillofacial Surgery in Liverpool they evaluated 200 consecutive patients undergoing primary surgery for previously untreated oral and oropharyngeal squamous cell carcinoma. Of the 200 patients, $107(53.5 \%)$ had a clear margin, $42 \%$ had a close margin and $4.5 \%$ had involved margin. They defined the clear margin as no evidence of tumor within $5 \mathrm{~mm}$ of the margin on histological assessment of formalin fixed. They defined the close margin as tumor within $5 \mathrm{~mm}$ of the margin but no evidence of tumor at the margin and they defined the involved margin as evidence of frank tumor at the margin. Their follow-up data shows that close surgical data resection margins were associated with a shorter 
disease free and disease specific survival. At five years $78 \%$ of patients were alive and well or dead and free of disease, compared to $47 \%$ of those with close margins and $11 \%$ of those with involved margins. Patients with close surgical margins were at significantly greater risk of developing local recurrence (clear $12 \%$, close $33 \%$ and involved $55 \%$ ) or regional recurrence (clear $4 \%$, close $10 \%$ and involved $22 \%$ ). Their five year overall survival was $54 \%$ for patients with clear margin, $26 \%$ for patients with close margin and none of the involved margins survived five years. In their multivariate Cox regression analysis the relative risk of death associated with involved margin was 11.6, close margin was 2.66 and positive cervical nodes was 2.15 . They report that the reason for the lower degree of significance in the positive cervical node group was that only 99 patients had nodal disease.

In a multivariate analysis on 303 patients treated with primary radical radiotherapy followed by surgery, Jones and his colleague (97) failed to confirm any independent adverse effects from positive margins. They reported their five-year tumor specific survival of patients with positive margin to be $31 \%$ compared to $43 \%$ for negative margin. On their Cox regression analysis gender and neck node recurrence were the only predictor of survival. The absence or presence of positive resection margin was not an independent predictor factor of survival.

McMahon and his colleagues (86) reported their findings in two independent groups of patients. Two hundred and thirty-seven patients with oral and oropharyngeal carcinoma were treated in Sydney, Australia and 95 patients were treated in Lanarkshire, England. On a univariate analysis a number of factors significantly predict the local recurrence in each group. In the Sydney group the condition of margins was one of them. 
While in the Lanarkshire group the status of the surgical margin did not predict the local recurrence on a univariate analysis. However, on a multivariate analysis only the observation of perineural invasion at the primary tumor site was an independent predictor of local recurrence. This applied to both groups of patients. When disease specific survival was studied on the univariate analysis the condition of margins was a significant prognostic indicator of the five-year disease specific survival in both groups. However, on multiple regression analysis only the presence and extent of regional nodal involvement independently influenced the disease specific survival. They concluded in their study that for most patients who have a close or involved margin the biology of the disease influences the subsequent course irrespective of the width of clearance of tumor. 


\section{Radiation Therapy and Positive Margins}

Postoperative radiation therapy has an established role in the management of advanced squamous cell carcinoma of the head and neck. Amadur(98) in 1989 and Jacob in 1993 (85) reported that the local failure in patients that were treated with surgery with positive margins followed by adjuvant radiation therapy was higher than the patients with negative margins. One important factor influencing local control in patients with positive margins is dose of postoperative radiotherapy. Zelefsky et al (99) reported a seven-year local control of $92 \%$ in patients who received greater than 60 Gray compared with $44 \%$ in patients who received less than 60 Gray.

Beitler et al (100) reported a study of 29 patients with microscopically close or positive margins after curative surgery treated with postoperative external beam radiotherapy to a median dose of 60 Gray followed by iodine- 125 permanent implant designed to deliver an accumulative life-time dose of 120 - 160 Gray to the high risk target volume. This treatment strategy resulted in $92 \%$ two-year local control.

\section{Molecular margins}

The advancement in basic research, genomics, and proteomics in this decade have improved the understanding of the molecular process of head and neck cancer, and it will guide the process in applying these research topics clinically to predict cancer before its clinical appearance, improve staging, assess response to treatment, and determine the molecular margin (101).

Most of the studies on molecular surgical margin were concentrating on the P53 mutation using a mutation specific plaque hybridization assay. Using molecular probes 
for mutation of P53, Bernnan et al (102) found "molecular positive margin" in more than $50 \%$ of patients who had a completely resected carcinoma. These patients manifested a higher risk of local failure. Although, Odgen et al (103) found no evidence to support Bernnan's results.

Nathan et al (104) identified the translation initiation factor eIF4E using immunohistochemical methods as a powerful oncogene. Franklin et al (105) used this marker in a study of laryngeal and hypopharyngeal cancer, Twelve of 13 patients with no detectable eIF4E in histologically negative margin were disease free. Of the 18 patients with overexpressed protooncogene in the margins $67 \%$ developed recurrence. Although, this molecular studies are promising they require significant time which limit their intraoperative use.

Goldenberg et al (106) tried to detect and quantify tumor-specific methylated promoter sequences in surgical margins in a time frame suitable for intraoperative use using a quantitative methylation-specific polymerase chain reaction (QMSP) protocol. On 13 patients with head and neck squamous cell carcinoma they used harbor promoter hypermethylation for p16 and O6-methylguanine-DNA-methyltransferase (MGMT) genes. Rapid QMSP was then used to identify promoter hypermethylation of these genes in the surgical margins. They compare the results of intraoperative histologic frozen section analysis to conventional QMSP. They found that 3 patients had methylationpositive margins. Tumor margins from 2 patients were methylated for p16 alone, and margins from 1 patient were methylated for p16 and MGMT simultaneously. Molecular margin analysis was completed in less than 5 hours and this technique was comparable in sensitivity to conventional QMSP. 


\section{MATERIALS AND METHODS}

This is a population based historical cohort analysis. The charts of 707 patients registered with squamous cell carcinoma of the oral cavity excluding the lip registered in the Province of Manitoba from January 1975 to December 2003 were evaluated. Of these 707 patients, 638 were treated with curative intent, 179 patients were treated with radiation therapy as a single treatment modality were excluded. Thirty-four patients were excluded due to incomplete records. A total of 425 cases of biopsy-proven and previously untreated squamous cell carcinoma of the oral cavity were identified. The review focused on the patient demographics, presenting signs and symptoms of the disease, treatment modalities, and treatment failure. Tumor staging was done using clinical data recorded at the time of initial assessment of each patient according to the TNM (tumor, node and metastasis) classification system of the International Union Against Cancer, 2002. (6) After appropriate merges and data transformation, statistical analysis was done using SPSS software (SPSS Inc., Chicago, IL). Descriptive statistics are presented as mean \pm standard deviation (SD) for continuous variables and percent (\%) and sample size (n) for categorical variables. The comparison between the study groups was done for baseline characteristics using Pearson chi-square, with continuity correction when appropriate, or Fisher's exact test for categorical variables and t-test or Mann-Whitney Utest for continuous variables. Kaplan-Meier (107) curves comparing time-to success (survival) probabilities between the two study groups, using the Log-rank test, was done. A multivariable Cox's proportional hazard model (108) tested the hypothesis of increased hazard of failure with positive margins after controlling for potentially confounding 
variables, such as site, age, tumor stage, etc., was done. In addition, this model produced the adjusted hazard ratios and the estimated adjusted probabilities of success (survival) for each predictor in the model. 


\section{RESULTS}

Patient Demographics: There were 250 men and 175 women, with a mean age of

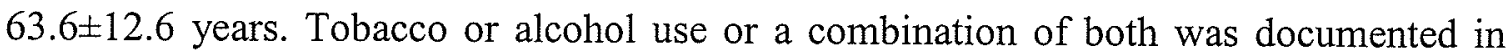
$(80 \%)$ of patients. Diabetes, hypertension and ischemic heart disease were the most common Comorbidities recorded. 198-second primaries malignancies were identified in 145 patients, of which $61 \%$ were metachranous.

Site: The tongue was the primary site in $30.4 \%$ of patients, floor of mouth in $39.8 \%$ (169), 9\% (38) in the lower alveolus, $7.8 \%$ (33) buccal mucosa, $5.4 \%$ in the upper alveolus, and $7.8 \%$ in the retromolar trigone.

Staging: The TNM staging on presentation is shown in (Table1). One hundred and twenty-four patients had Stage I lesions, while 118,68,and 105 patients had Stage II, III, and IV disease respectively. One hundred and seven patients (26\%) had clinically positive nodes at the time of presentation. One patient had a distant metastases at the time of presentation.

Treatment: Surgery was used as the only treatment modality in 298 patients (70.1\%). One hundred and twenty seven patients $(29.9 \%)$ received adjuvant radiotherapy.

Transoral excision of the primary tumor was performed in 230 patients, whereas 195 required a cheek flap for exposure. 175 required mandibular resection, either a marginal resection (65 patient) or segmental mandibulectomy (113 patients). Partial maxillectomy was performed in 4 patients and total maxillectomy in 6 patients. Primary closure was possible in 197 patients. Two patients were reconstructed with a maxillary prefabricated acrylic obturator. One hundred and forty two patients require soft tissue 
reconstruction only, in which a split-thickness skin graft in 6, Pectorals major in 37 , and a free flap in the reminder. The mandible was reconstructed in 86 patients.

Margins on permanent section were involved 62 patients and close (within $2 \mathrm{~mm}$ ) in 68 and clear in 295. Intraoperative frozen sections were used in 225 patients. Of those 225 patients 158 had clear margin on the permanent section, 31 had close margin, and 36 had involved margin.

One hundred and five patients with clinically positive cervical nodes were managed with a neck dissection, a comprehensive modified neck dissection in 55 patients and a standard neck dissection in 50. Fifty-three of these patients received adjunctive radiotherapy. Two patients with $\mathrm{N}+$ neck were treated with radiation alone. The clinically negative neck was treated electively in 120 of 308 patients with surgery and 46 patients received adjuvant radiotherapy. Of the ten patients that were not staged 3 received surgical treatment to the neck.

Treatment Failure and Survival: The overall median survival time was greater than 60 months and $61.9 \%$ of the patients survived the 5-year period. When disease specific survival was considered $74.5 \%$ of the patients survived the 5 -year period and median survival time was still above 60 months. The median disease-free survival was also above 60 months and only $60.3 \%$ of patients had 5-year disease free survival. Patients younger than 65 years had a better survival when compared to those 65 years or older: $69 \%$ versus $53 \%$ respectively $(\mathrm{p}<0.025)$. Gender differences did not significantly affect overall survival $(p>0.1)$ neither did the site of primary tumor $(p>0.9)$ all staging classifications were significantly related to 5 -year survival: Stage $(\mathrm{p}<0.0001)$, T-stage $(\mathrm{p}<0.0001), \mathrm{N}$ stage $(p<0.005)$. Surgery as the only treatment modality led to better survival when 
compared to surgery and radiotherapy $66 \%$ versus $53 \%(\mathrm{p}<0.025)$. Clear surgical margin shad the best survival rate (69\%) compared to both close margin (58\%) and involved margin $(38 \%)(\mathrm{P}<0.0001)$. Both clear and close margins had a median survival time $>60$ months, while involved margins had a median survival time of only 31 months $(95 \% \mathrm{Cl}=0,70) .($ Table 2 , Fig1-13)

Local and regional failure was observed in 115 patients (27\%). In the clear margin group 64 patients failed which form $21 \%$ of this group, while in the close margin group 24 patients (35\%) failed treatment, and 27 patients in the involved margin group which form $43 \%$ of this group.

Multivariable Cox's proportional hazard modeling revealed that involved margins increase the risk of 5-year overall death by $90 \%$ (HR1.9; 95\%CI=1.2,2.9; $\mathrm{P}<0.005)$ after controlling for age, T-stage, and N-stage in the final model. (Table 3) 


\section{Discussion}

This historical cohort study of patients with squamous cell carcinoma of the oral cavity is relatively large. It is comparable in most respects, including the age and sex distribution, site distribution, etiologic factors, and incidence of second primaries, to most series of oral cancer. This study is one of few studies that show the significance of surgical margins on prognosis in both univariate and multivariate analysis. We find a significant difficulty in comparing our study to other previously published studies on margin status due to the lack of standardization in defining a clear, close, and a positive margin.

Loree and Strong 1990(82) used four criteria to define a positive margin. Close margin (within $0.5 \mathrm{~cm}$ ), premalignant changes at the margin, carcinoma in situ in the margin, and invasive microscopic cancer at the margin. Their study showed 5-year over all survival with a negative margin of $60 \%$, premalignant changes; $94 \%$, carcinoma in situ; $71 \%$, close; $51 \%$, and; $43 \%$ for microinvasive carcinoma. This study showed an increase in local recurrence in all four groups when compared to the negative margin. Amdur et al (98), found no differences in recurrence rate in tumors with negative resection margins and carcinoma in situ at the resection margin. Batsakis (83) in his review suggests that there isn't enough data to conclude that carcinoma in situ or dysplasia should be considered as a positive margin. Therefore we only considered invasive carcinoma as a positive margin in our study. The use of $5 \mathrm{~mm}$ as defining a close margin is an arbitrary number that several studies adopted following the reports of Looser et al 1978 (11). Batsakis (83) suggested that all studies should use $5 \mathrm{~mm}$ as a uniform even though there is not sufficient data in the literature showing that $5 \mathrm{~mm}$ is the right 
number. In Yuen et al (89) review of 50 glossectomy specimens a higher local recurrence rate was observed with a close resection margin of less than $2 \mathrm{~mm}$. Our data shows that overall 5 -year survival changes significantly when the margin is less than $2 \mathrm{~mm}$, and there was no improvement in survival between $5 \mathrm{~mm}$ and clear margins. Spiro et al (87) defines a close margin as tumor within one high- power field of the edge of the specimen suggesting that this measure may be more accurate and reproducible.

Frozen section in our study appeared accurate in the order of $96-98 \%$ as reported by others $(94,109-112)$. Our findings show that the use of intraoperative frozen sections does not eliminate the presence of positive or close margin in the final specimen. Use of frozen section did not influence the outcome. This finding has been observed by others $(94,106)$. We contribute this to the sampling technique and error especially in the deep margin. The lack of communication between the surgeon and pathologist may contribute as well.

This study has shown that the overall local recurrence rate in the positive margin was twice the negative margin group. Studies by Looser et al (11), Loree and Strong (82), Spiro et al (87), Jacob et al (85), Sutton et al (96) have shown similar results and this is despite the differences in defining clear, close, and positive margins. These differences in definition may also explain the higher 5 -year survival in the positive margin group as reported by Loree \& Strong (82) (52.7\%) when compared to ours (38\%). Sutton et al (96) on Cox regression analysis observed that the status of the surgical margin was an independent predictor of survival and altered the prognosis with a similar magnitude to that observed with positive neck nodes. This was our observation as well. Jones et al (97) failed in his multivariate analysis to confirm any independent adverse effect from a 
positive margin. It is noted however that only 59 of his 352 patient, treated with primary radiation followed by surgery, had primary oral SCC. The reminder were in different sites of the head and neck with the larynx forming more than $40 \%$ (150 patients) This may explain there findings. McMahon et al (86) in 332 patients with carcinoma of the oral cavity and oropharynx observed that the margin status was a predictor of local recurrence on univariate testing in 237 patients of his study. On multivariate analysis perineural invasion was the only predictor of local recurrence and lymph node involvement was a predictor of disease specific survival. They failed to demonstrate that the condition of the surgical margin had any independent predictive effect on local recurrence or survival on multivariate analysis. Other studies $(76,89,90$, ) have also demonstrated the role of perineural invasion as independent prognostic factor of local recurrence. Perineural invasion was not assessed in our study.

On multivariate analysis our study did not show in improvement in survival with the use of adjuvant radiotherapy. This was also observed by others $(95,96,113)$. Sadeghi et al (114) observed a 2-year survival of $41 \%$ for surgery alone, and $62 \%$ for patients who received adjuvant radiotherapy. Vikram et al (115) observed that postoperative radiotherapy of 6000CGy in the presence of positive margins will improve local control but will not affect survival. Although it is believed that post operative radiotherapy will not improve survival in patients with positive or close margin, it may improve local control.

There have been several studies that evaluate the surgical margin in a different way than visual inspection by using the molecular margins as an indicator for prognosis such 
as $\mathrm{P} 53$, and translation initiation factor eIF4E with the use of immunohistochemical techniques (101-106). These methods show a promise to direct treatment in the future.

There are limitations to our study. The histopathology reviewed concentrated on the margin status as clear, close, or positive without reviewing the tumor host interface and the histology grading. Future studies should control for these factors as well as perineural invasion.

In conclusion the status of the surgical margin is an important predictor of outcome. The surgical margin, in contrast to the other prognostic indicators, is under the direct control of the surgeon. Multicenter prospective studies are necessary to provide uniform definitions of clear, close and positive margins. 
VI. TABLES

Table 1. Baseline Characteristics

\begin{tabular}{|c|c|c|}
\hline Variable & $\mathbf{N}$ & $\%$ Percent \\
\hline \multicolumn{3}{|l|}{ Site } \\
\hline Tongue & 129 & 30.4 \\
\hline Floor of Mouth & 169 & 39.8 \\
\hline Lower Alveolus & 38 & 8.9 \\
\hline Buccal Mucosa & 33 & 7.8 \\
\hline Upper Jaw & 23 & 5.4 \\
\hline Retromolar Trigone & 33 & 7.8 \\
\hline \multicolumn{3}{|l|}{ Gender } \\
\hline Male & 250 & 58.8 \\
\hline Female & 175 & 41.2 \\
\hline \multicolumn{3}{|l|}{ Age Category } \\
\hline$<65$ years & 225 & 52.9 \\
\hline+65 years & 199 & 46.8 \\
\hline \multicolumn{3}{|l|}{ Stage } \\
\hline I & 124 & 29.9 \\
\hline II & 118 & 28.4 \\
\hline III & 68 & 16.4 \\
\hline IV & 105 & 25.3 \\
\hline \multicolumn{3}{|l|}{ Stage $\mathbf{T}$} \\
\hline $\mathrm{T} 1$ & 130 & 31.3 \\
\hline $\mathrm{T} 2$ & 167 & 40.1 \\
\hline T3 & 42 & 10.1 \\
\hline $\mathrm{T} 4$ & 77 & 18.5 \\
\hline \multicolumn{3}{|l|}{ Stage $N$} \\
\hline No & 308 & 74.2 \\
\hline N1 & 64 & 15.4 \\
\hline N2 & 41 & 9.9 \\
\hline N3 & 2 & 0.5 \\
\hline \multicolumn{3}{|l|}{$\begin{array}{l}\text { Major Treatment } \\
\text { Modality }\end{array}$} \\
\hline Surgery & 298 & 70.1 \\
\hline Surgery and Radiotherapy & 127 & 29.9 \\
\hline \multicolumn{3}{|l|}{ Margin } \\
\hline Clear & 295 & 69.4 \\
\hline Close & 68 & 16 \\
\hline Involved & 62 & 14.6 \\
\hline
\end{tabular}


Table 2. 5-year Overall Survival Probabilities by Major Demographic and Clinical Variables:

\begin{tabular}{|c|c|c|c|}
\hline Variable & $\mathbf{N}$ & $\begin{array}{l}\text { 5-Year Survival } \\
\text { Probability }\end{array}$ & P-Value \\
\hline Site & & & 0.9746 \\
\hline Tongue & 129 & 0.64 & \\
\hline Floor of Mouth & 169 & 0.63 & \\
\hline Lower Alveolus & 38 & 0.63 & \\
\hline Buccal Mucosa & 33 & 0.69 & \\
\hline Upper Jaw & 23 & 0.45 & \\
\hline Retromolar Trigone & 33 & 0.62 & \\
\hline Gender & & & 0.1348 \\
\hline Male & 250 & 0.59 & \\
\hline Female & 175 & 0.66 & \\
\hline Age Category & & & 0.0166 \\
\hline$<65$ years & 225 & 0.69 & \\
\hline+65 years & 199 & 0.53 & \\
\hline Stage & & & 0.0000 \\
\hline I & 124 & 0.76 & \\
\hline II & 118 & 0.65 & \\
\hline III & 68 & 0.59 & \\
\hline IV & 105 & 0.45 & \\
\hline Stage $T$ & & & 0.0000 \\
\hline $\mathrm{T} 1$ & 130 & 0.75 & \\
\hline $\mathrm{T} 2$ & 167 & 0.63 & \\
\hline $\mathrm{T} 3$ & 42 & 0.52 & \\
\hline $\mathrm{T} 4$ & 77 & 0.43 & \\
\hline Stage $\mathbf{N}$ & & & 0.0037 \\
\hline No & 308 & 0.66 & \\
\hline N1 & 64 & 0.55 & \\
\hline $\mathrm{N} 2$ & 41 & 0.46 & \\
\hline N3 & 2 & 0.00 & \\
\hline $\begin{array}{l}\text { Major Treatment } \\
\text { Modality }\end{array}$ & & & 0.0249 \\
\hline Surgery & 298 & 0.66 & \\
\hline Surgery and & 127 & 0.53 & \\
\hline Radiotherapy & & & \\
\hline Margin & & & 0.0000 \\
\hline Clear & 295 & 0.68 & \\
\hline Close & 68 & 0.58 & \\
\hline Involved & 62 & 0.38 & \\
\hline
\end{tabular}


Table 3: Cox's Proportional Hazard Model Predicting 5-year Overall Survival:

Variable

$\underline{\text { Hazard Ratio }}$

95\% CI

$\underline{\text { P-Value }}$

Included in the

Model

Involved margin Vs. $\quad 1.9$

Clear or Close

Age $65+$ years Vs. $\quad 1.5$

$<65$ years

T-Stage

1.4

$\mathrm{N}$-Stage

1.3

$(1.2,2.9)$

0.0026

Excluded from the

model

Close margin Vs.

Clear margin

Gender

$\begin{array}{ll}(1.1,2.2) & 0.0177\end{array}$

Treatment Modality

0.1027

Stage

$(1.2,1.6)$

0.0002

$(1.004,1.626)$

0.0465

Site

0.3212

0.6105

0.8805

0.8379 


\section{FIGURES}

\section{Figure 1:}

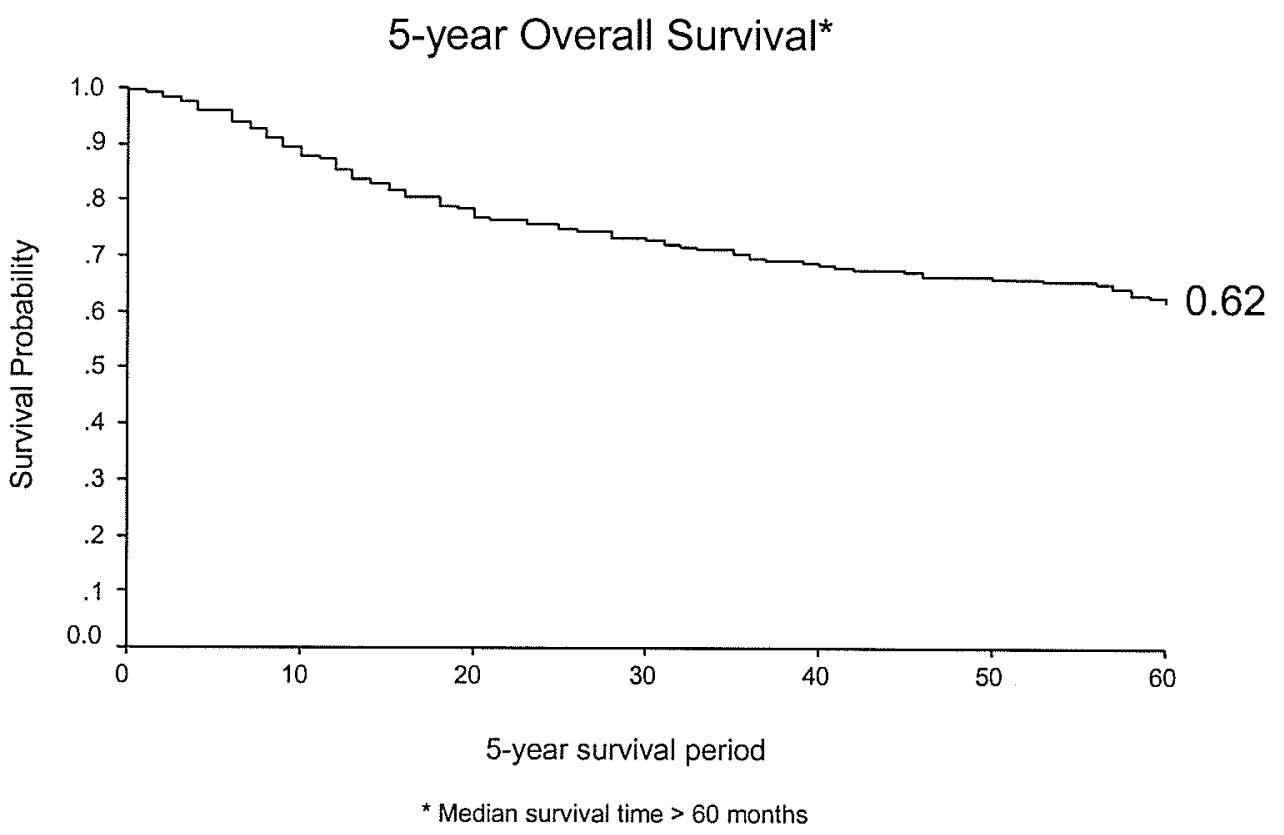




\section{Figure 2}

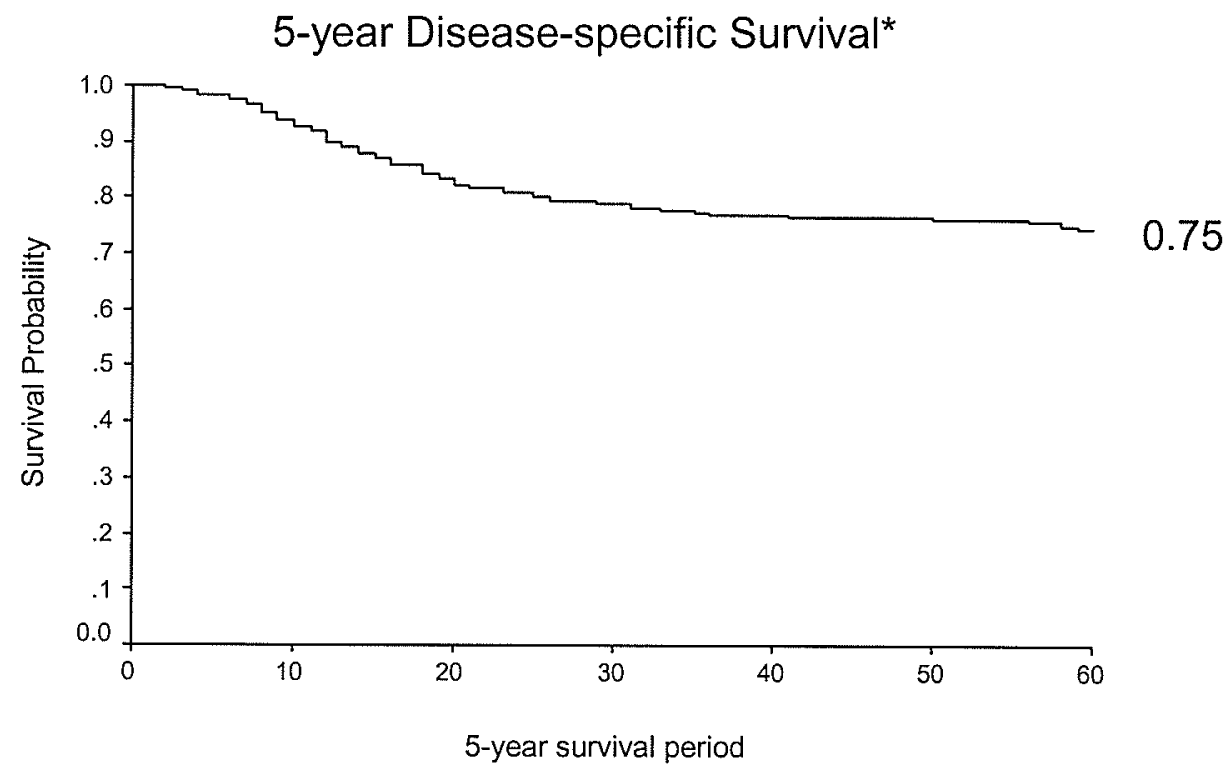

*Median disease-specific survival time $>60$ months 


\section{Figure 3}

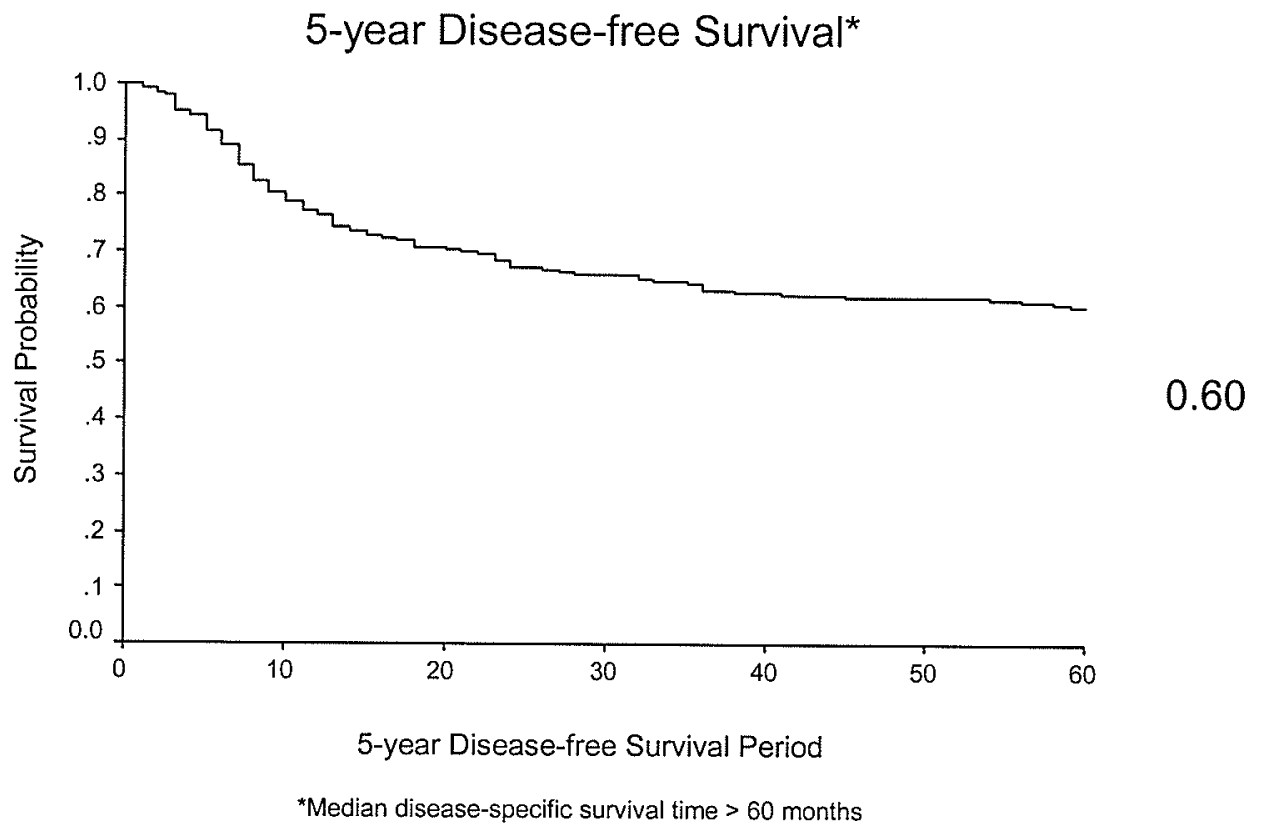




\section{Figure 4}

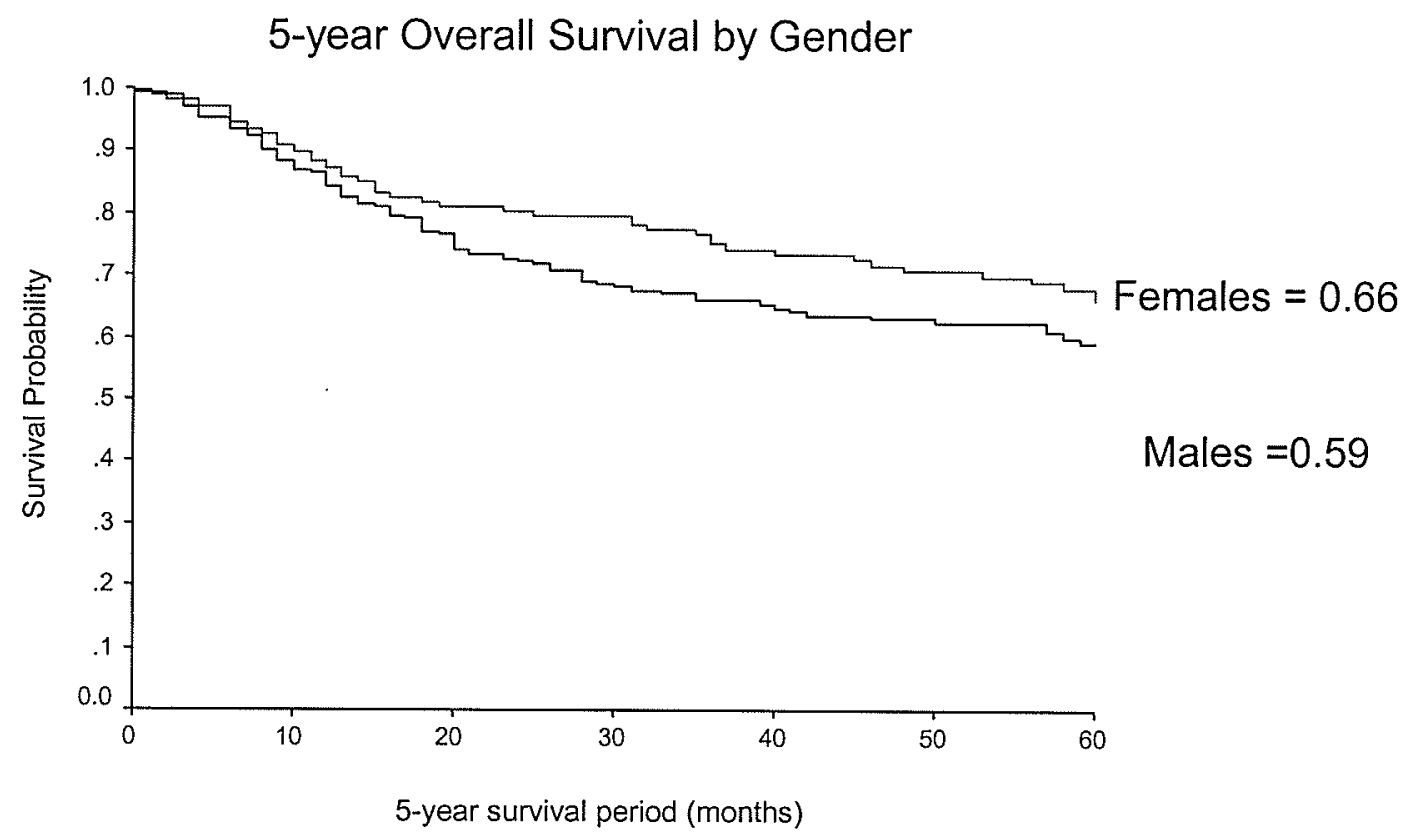

Log-rank test $P$-value $=0.1348$ 


\section{Figure 5}

5-year Overall Survival by Age Category

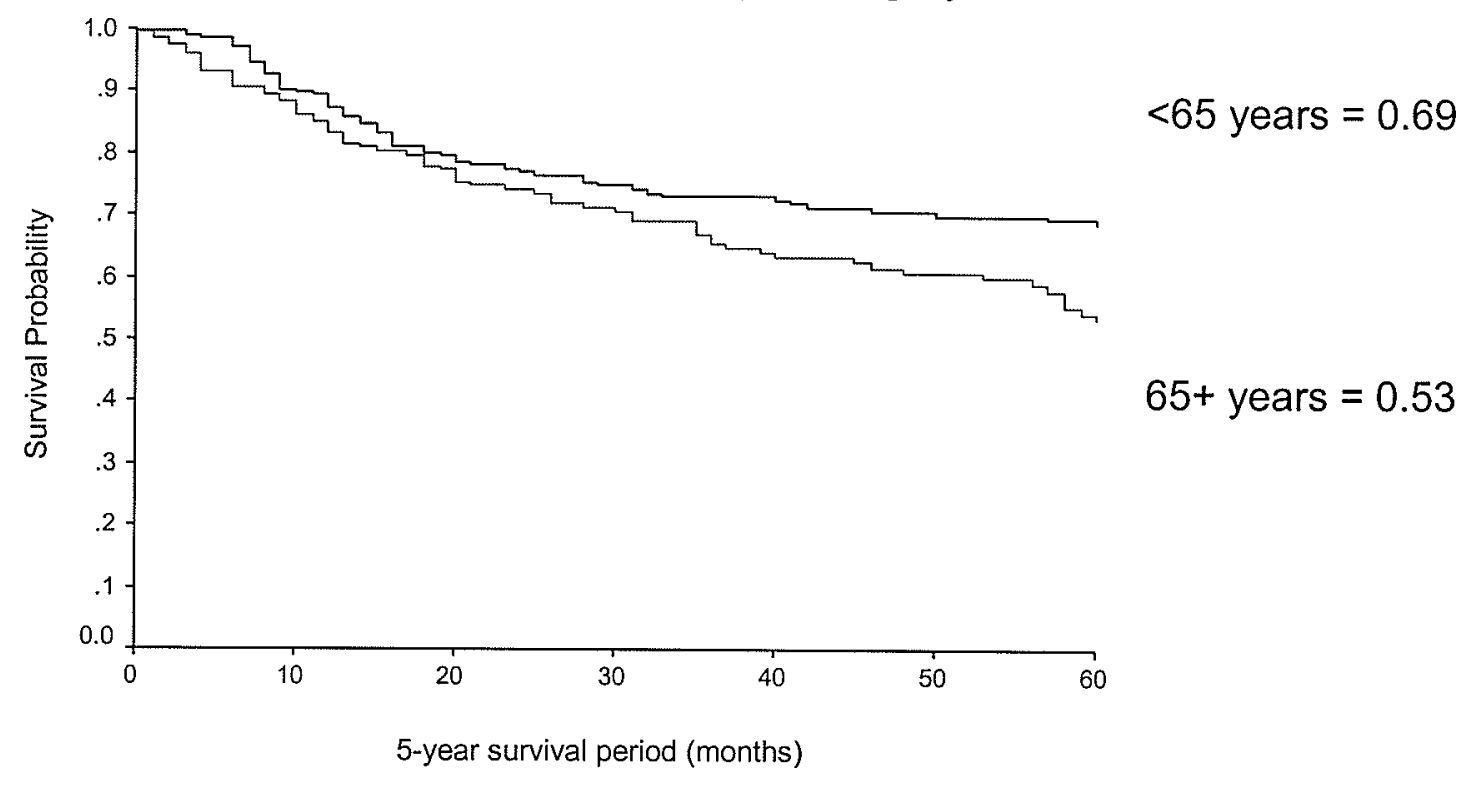

Log-rank test $P$-value $=0.0166$ 


\section{Figure 6}

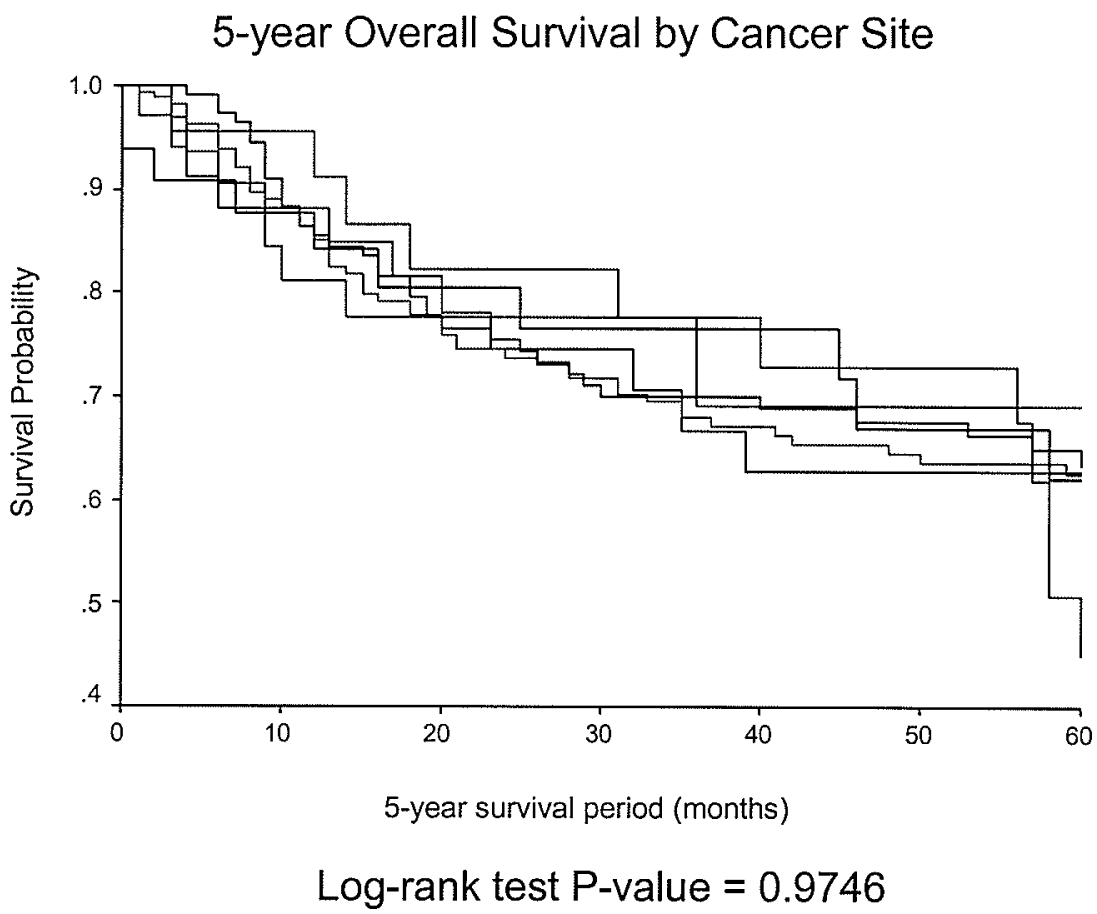




\section{Figure 7}

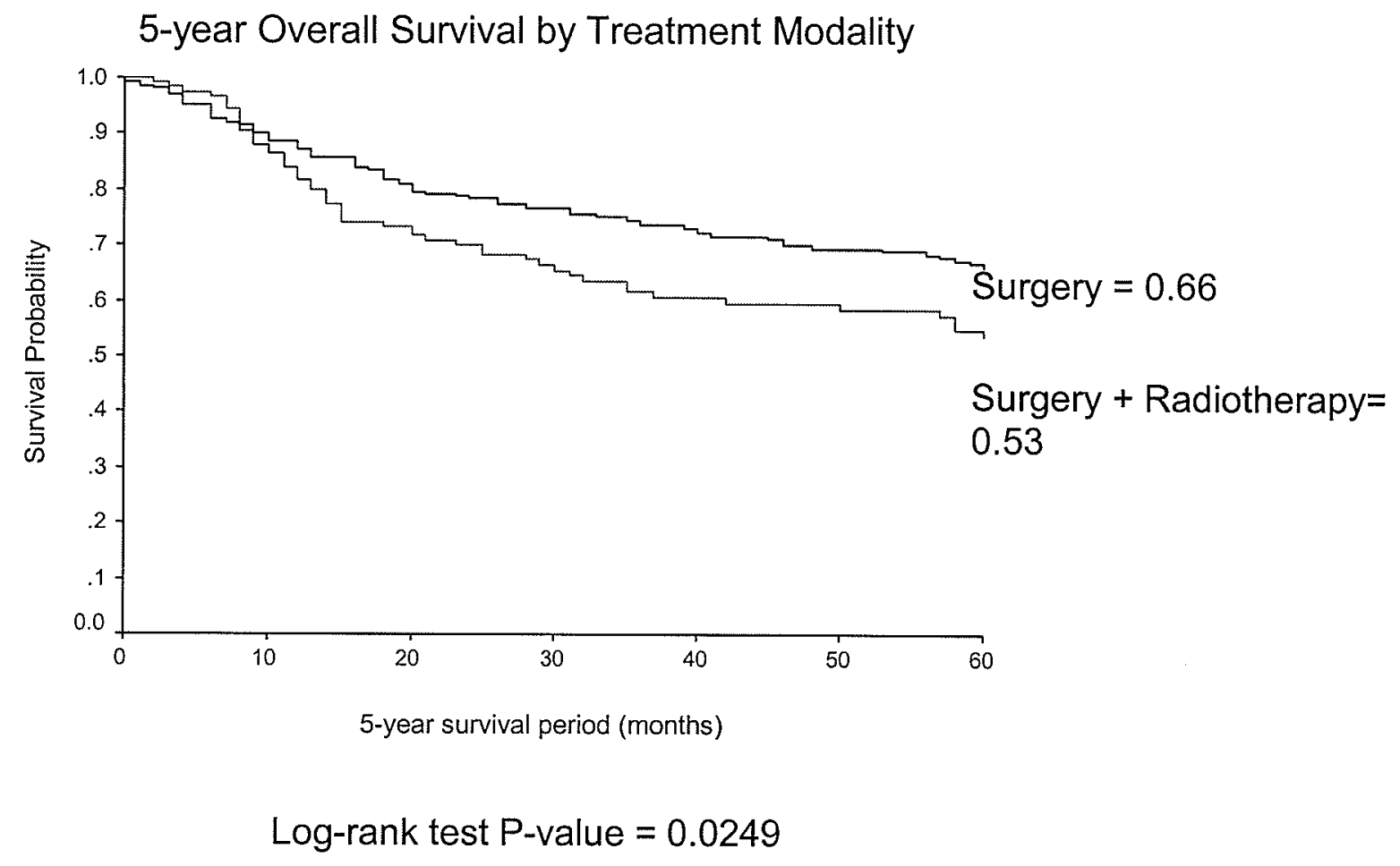




\section{Figure 8}

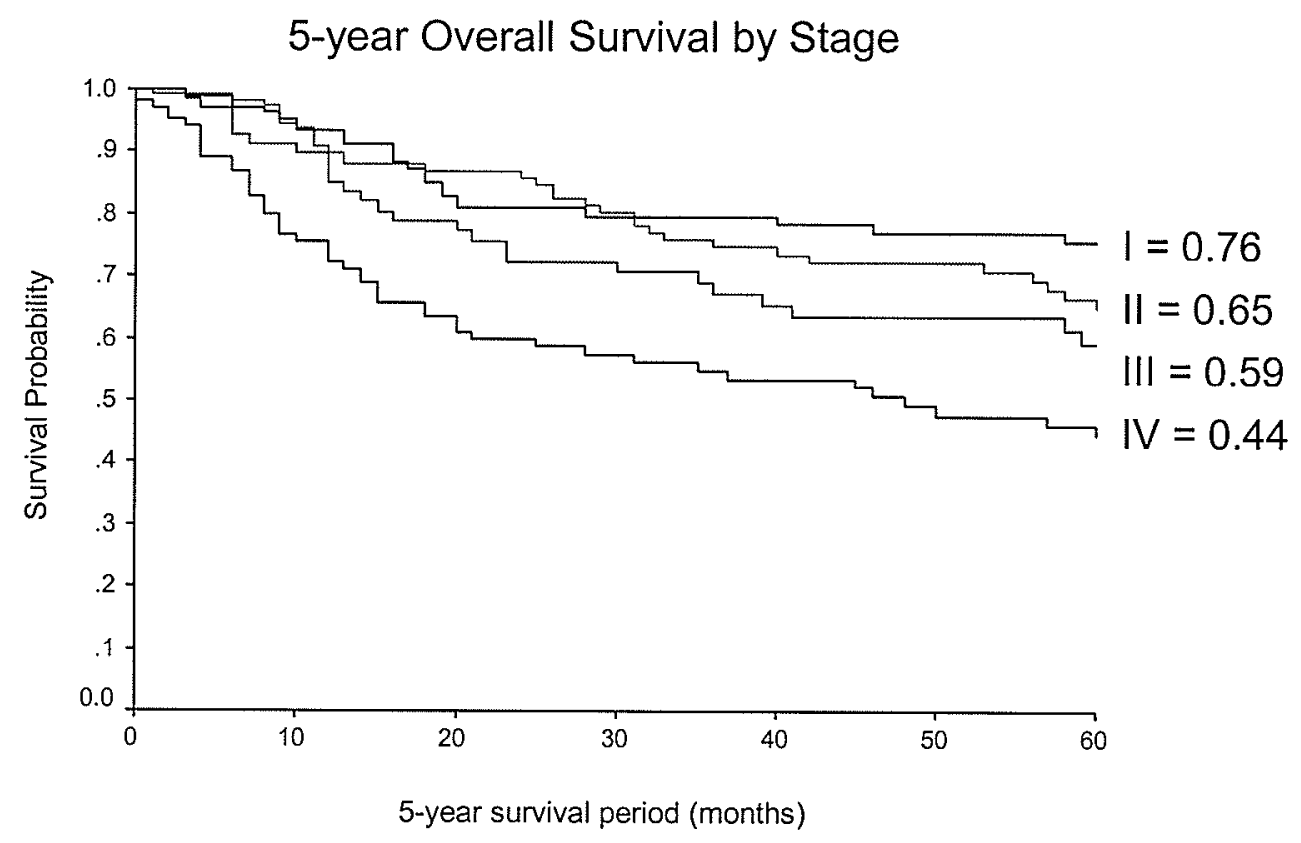

Log-rank test $\mathrm{P}$-value $=0.0000$ 


\section{Figure 9}

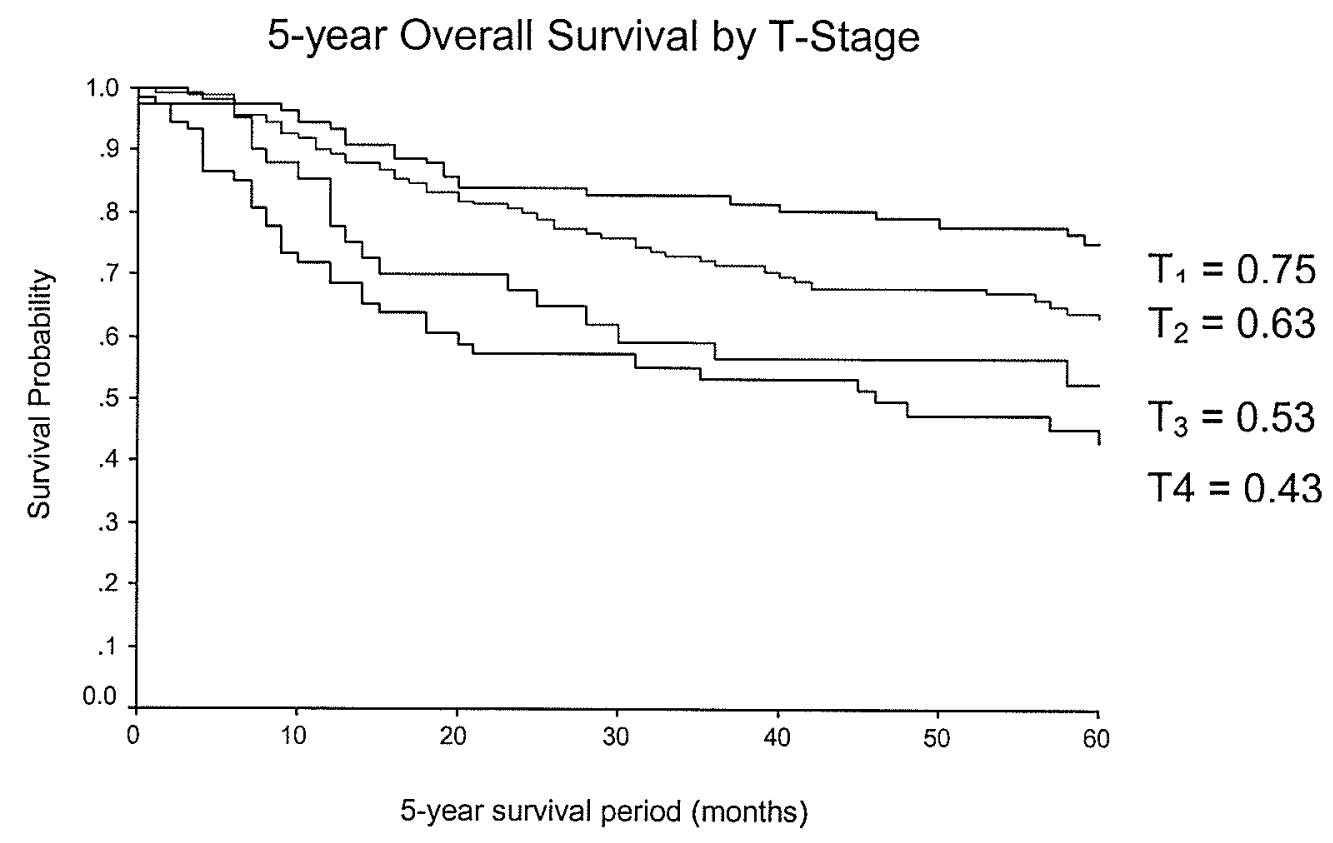

Log-rank test $P$-value $=0.0000$ 


\section{Figure 10}

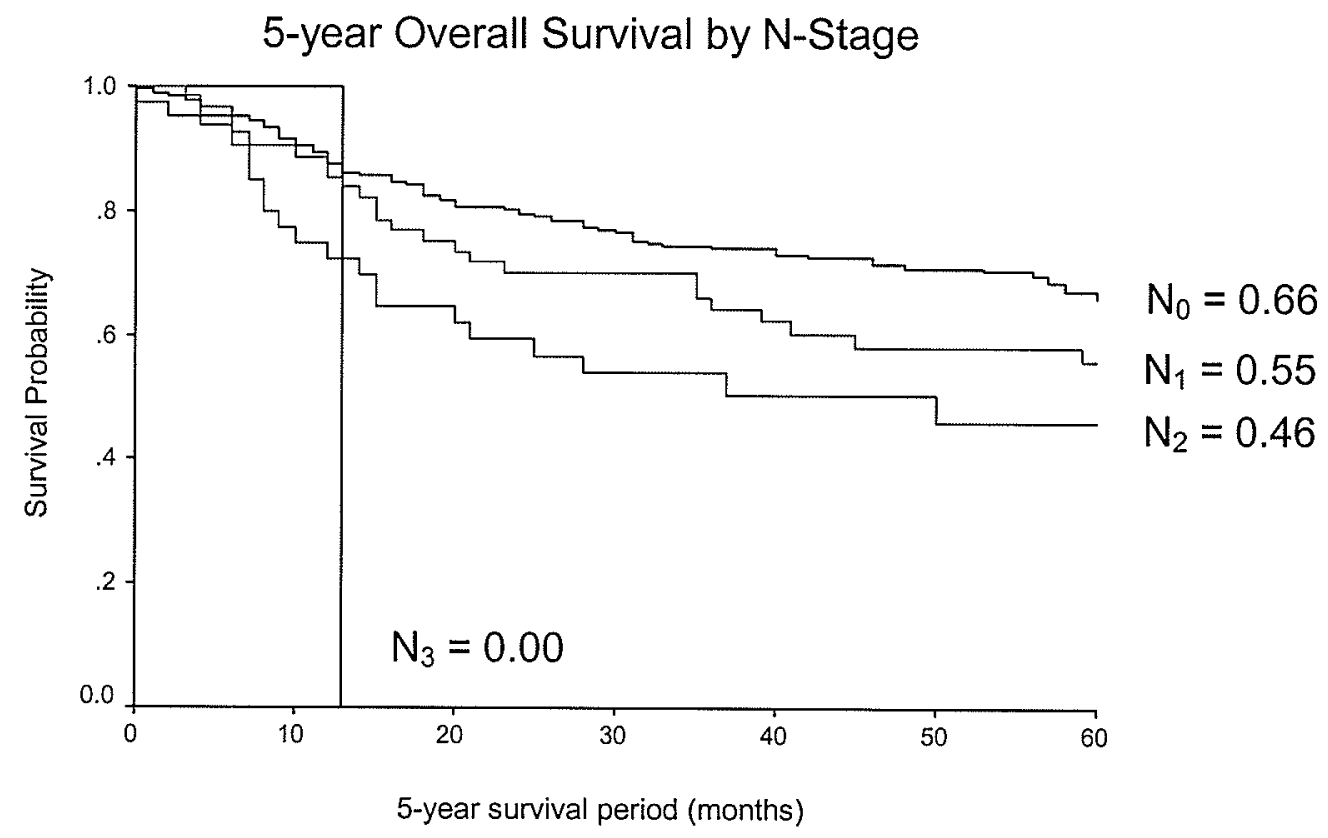

Log-rank test $P$-value $=0.0037$ 


\section{Figure 11}

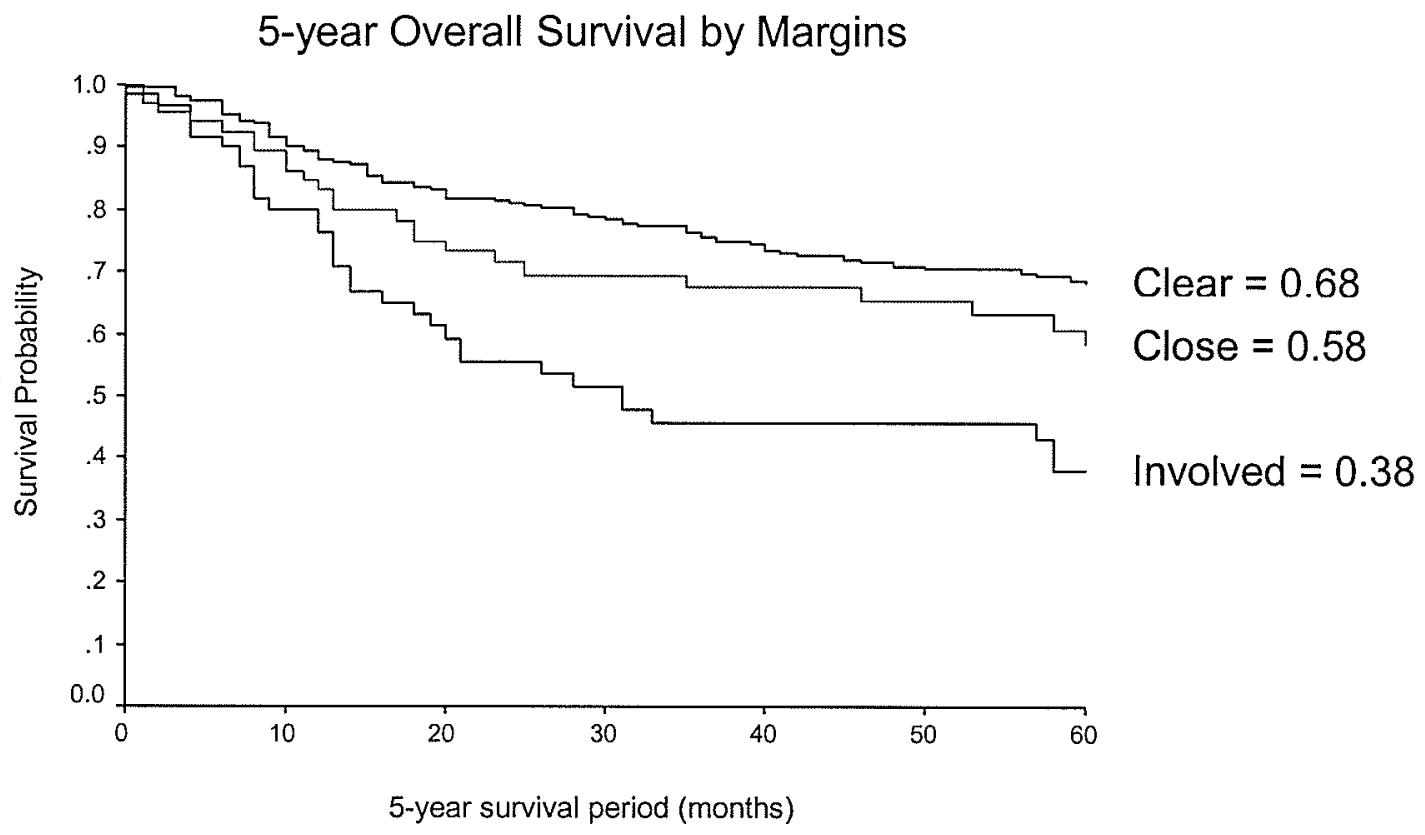

Log-rank test $P$-value $=0.0000$ 


\section{Figure 12}

\section{Estimated 5-year Survival Pattern by Sugical Margins}

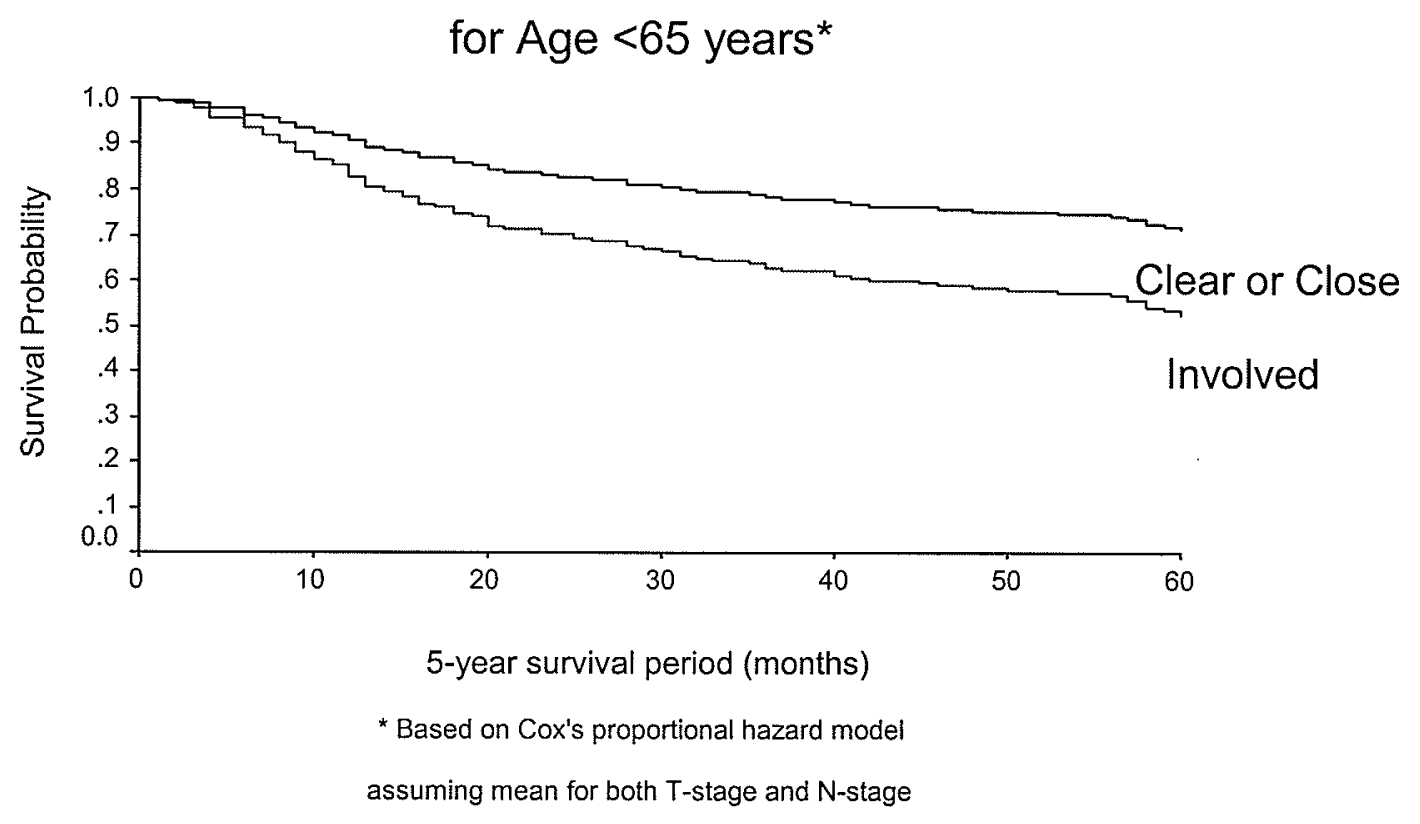




\section{Figure 13}

\section{Estimated 5-year Survival Pattern by Surgical Margins}

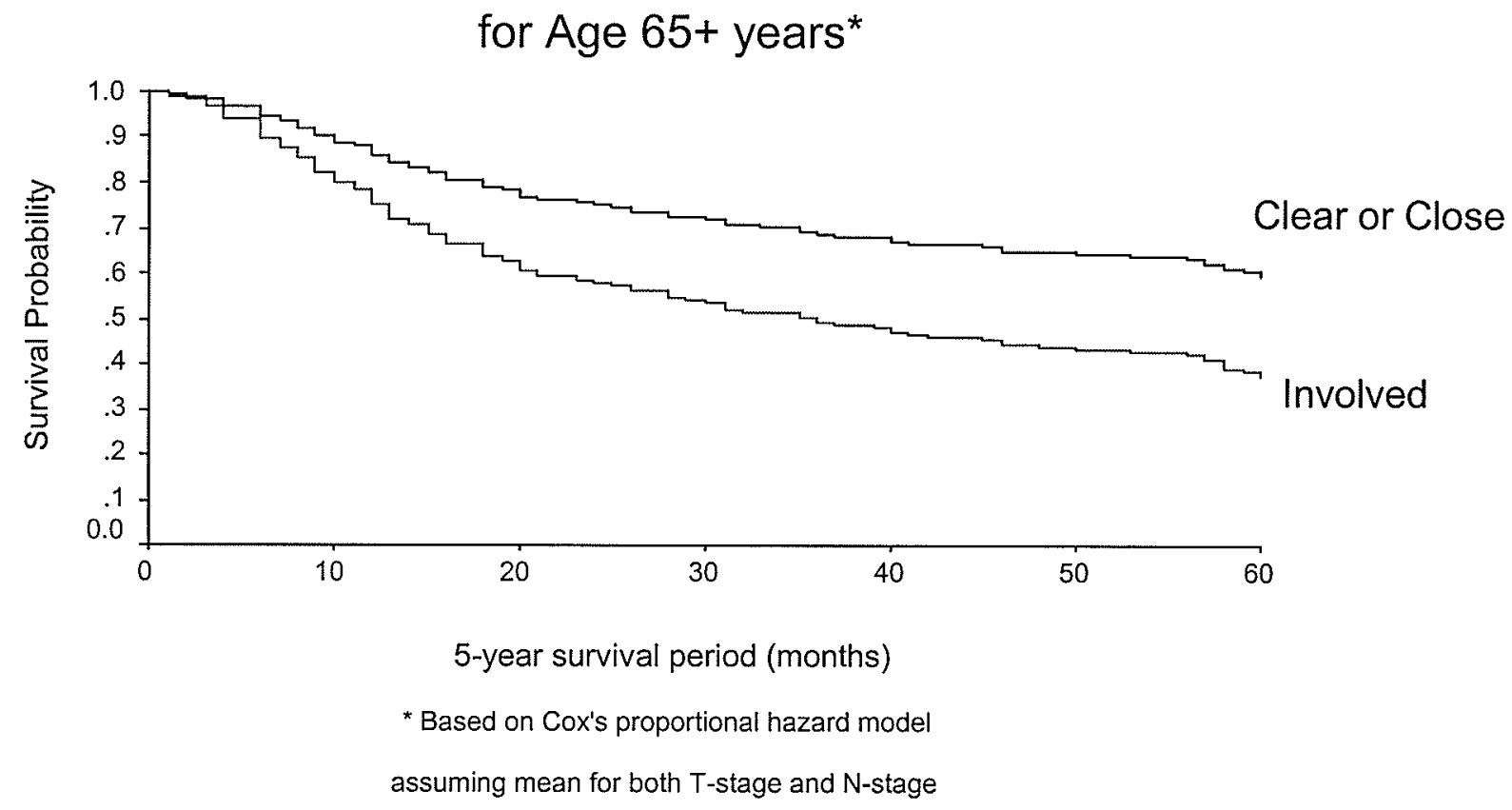




\section{REFERANCES}

1. Jemal A, Murray T, Samuels A, et al: Cancer statistics, 1999. CA Cancer J Clin $53: 5,2003$.

2. Canadian cancer statistics 2004 .

3. Muir G, Welland L. Upper aerodigestive tract cancer. Cancer 1995;75(suppl 1):147-153.

4. Silverman J: Oral cancer(4thed) Hamilton, Canada, The American Cancer Sociaty, 1998

5. Krolls S, Hoffman S, Squamous cell carcinoma of the oral soft tissues: a statistical analysis of 14,253 cases by age, sex, and race of patients.J Am Dent Assoc. 1976 Mar;92(3):571-4.

6. International Union Against Cancer. TNM Classification of Malignant Tumors $\left(6^{\text {th }}\right.$ ed). New York, Wiley-Liss, 2002 PP22-26

7. AJCC Cancer Staging Manual.Green FL, Page DL, Fleming ID, et al (eds.), $6^{\text {th }}$ ed, New York, Springer, 2002, PP35-46

8. McCarty PJ, Million RR. (1994) History of diagnosis and treatment of cancer in the head and neck. Management of Head and Neck Cancer: A Multidisciplinary approach, $2^{\text {nd }}$ ed. RR Million and NJ Cassis (eds) PP.1-29. JB Lippincott: Philadelphia.

9. Lee JG, Detection of residual carcinoma of the oral cavity, oropharynx, hypopharynx, and larynx: a study of surgical margins Trans Am Acad Ophthalmol Otolaryngol. 1974 Jan-Feb;78(1):ORL49-53. 
10. Byers RM, Bland KI, Borlase B, Luna M.The prognostic and therapeutic value of frozen section determinations in the surgical treatment of squamous carcinoma of the head and neck Am J Surg. 1978 Oct;136(4):525-8.

11. Looser KG, Shah JP, Strong EW.The significance of "positive" margins in surgically resected epidermoid carcinomas. Head Neck Surg. 1978 NovDec;1(2):107-11.

12. Chen TY, Emrich LJ, Driscoll DL., The clinical significance of pathological findings in surgically resected margins of the primary tumor in head and neck carcinoma. Int J Radiat Oncol Biol Phys. 1987 Jun; 13(6): 833-7.

13. Pisani P, Parkin DM, Ferlay J. Estimates of the worldwide mortality from eighteen major cancers in 1985. Implications for prevention and projections of future burden. Int J Cancer. 1993 Dec 2; 55(6): 891-903.

14. Johnson NW. Oral cancer: a world wide problem. FDI World 1997; 6(3): 19-21.

15. Peng J, Raverdy N, Ganry O, de La Roche-Saint-Andre G, Dubreuil A, Lorriaux A.. Descriptive epidemiology of upper aerodigestive tract cancers in the department of Somme Bull Cancer. 2000 Feb; 87(2): 201-6

16. Wunsch-Filho V, de Camargo EA. The burden of mouth cancer in Latin America and the Caribbean: epidemiologic issues. Semin Oncol. 2001 Apr;28(2):158-68

17. Moore SR, Johnson NW, Pierce AM, Wilson DF. The epidemiology of mouth cancer: a review of global incidence Oral Dis. 2000 Mar;6(2):65-74.

18. Moore SR, Johnson NW, Pierce AM, Wilson DF. The epidemiology of tongue cancer: a review of global incidence Oral Dis. 2000 Mar;6(2):75-84. 
19. Llewellyn CD, Johnson NW, Warnakulasuriya KA. Risk factors for squamous cell carcinoma of the oral cavity in young people--a comprehensive literature review. Oral Oncol. 2001 Jul;37(5):401-18.

20. Shah J. Global epidemiology,Oral cancer 2003 PP3-32

21. Oliver AJ, Helfrick JF, Gard D.Primary oral squamous cell carcinoma: a review of 92 cases.J Oral Maxillofac Surg. 1996 Aug;54(8):949-54

22. Baker SR. Malignant neoplasms of the oral cavity. In: Cummings $\mathrm{CW}$, ed. Otolaryngology: head and neck surgery. St. Louis: Mosby, 1993: 1248-1305.

23. Vincent RG, Marchetta F. The relationship of the use of tobacco and alcohol patients to cancer of the oral cavity, Pharynx or larynx . Am J Surg. 1963 Sep;106:501-5.

24. Johnston WD, Ballantyne AJ. Prognostic effect of tobacco and alcohol use in patients with oral tongue cancer. Am J Surg. 1977 Oct;134(4):444-7.

25. Silverman S Jr, Griffith M.Smoking characteristics of patients with oral carcinoma and the risk for second oral primary carcinoma. J Am Dent Assoc. 1972 Sep;85(3):637-40.

26.. International Agency for Research on Cancer. Tobacco smoking. IARC Monographs on the evaluation of carcinogenic risks to humans. Vol 38. Lyon: IARC, 1986.

27. Wynder EL, Mushinski MH, Stellman SD, Choay P.Tobacco and alcohol consumption in relation to the development of multiple primary cancers. Cancer. 1977 Oct;40(4 Suppl):1872-8. 
28. Franceschi S, Barra S, La Vecchia C, Bidoli E, Negri E, Talamini R. Risk factors for cancer of the tongue and the mouth. A case-control study from northern Italy. Cancer. 1992 Nov 1;70(9):2227-33.

29. Brown RL, Shu JM, Scarborough JE, Wilkins SA, Smith RR. Snuff dipper's intraoral cancer: clinical characteristics and response to therapy. Cancer 1965; $18: 2-13$

30. Ackerman LV. Verrucous carcinoma of the oral cavity. Surgery 1948; 23: 670678.

31. McCoy JM, Waldron CA.Verrucous carcinoma of the oral cavity. A review of forty-nine cases. Oral Surg Oral Med Oral Pathol. 1981 Dec; 52(6): 623-9

32. Sterling TD, Rosenbaum WL, Weinkam JJ.Analysis of the relationship between smokeless tobacco and cancer based on data from the National Mortality Followback Survey. J Clin Epidemiol. 1992 Mar; 45(3): 223-31.

33. Schildt EB, Eriksson M, Hardell L, Magnuson A.Oral infections and dental factors in relation to oral cancer: a Swedish case--control study. Eur J Cancer Prev. 1998 Jun; 7(3): 201-6

34. Lewin F, Norell SE, Johansson H, Gustavsson P, Wennerberg J, Biorklund A, Rutqvist LE.Smoking tobacco, oral snuff, and alcohol in the etiology of squamous cell carcinoma of the head and neck: a population-based case-referent study in Sweden. Cancer. 1998 Apr 1;82(7):1367-75.

35. Thomas S, Wilson A. A quantitative evaluation of the aetiological role of betel quid in oral carcinogenesis. Eur J Cancer B Oral Oncol. 1993 Oct; 29B(4): 26571. 
36. Gupta PC, Mehta FS, Daftary DK, Pindborg JJ, Bhonsle RB, Jalnawalla PN, Sinor PN, Pitkar VK, Murti PR, Irani RR, Shah HT, Kadam PM, Iyer KS, Iyer HM, Hegde AK, Chandrashekar GK, Shiroff BC, Sahiar BE, Mehta MN. Incidence rates of oral cancer and natural history of oral precancerous lesions in a 10-year follow-up study of Indian villagers.Community Dent Oral Epidemiol. $1980 ; 8(6): 283-333$

37. Kato I, Nomura AM.Alcohol in the aetiology of upper aerodigestive tract cancer. Eur J Cancer B Oral Oncol. 1994; 30B(2): 75-81

38. Schlecht NF, Pintos J, Kowalski LP, Franco EL.Effect of type of alcoholic beverage on the risks of upper aerodigestive tract cancers in Brazil. Cancer Causes Control. 2001 Sep; 12(7): 579-87.

39. Boffetta P, Mashberg A, Winkelmann R, Garfinkel L. Carcinogenic effect of tobacco smoking and alcohol drinking on anatomic sites of the oral cavity and oropharynx. Int J Cancer. 1992 Oct 21;52(4):530-3.

40. . Rennie JS, MacDonald DG. Cell kinetics of hamster ventral tongue epithelium in iron deficiency. Arch Oral Biol. 1984;29(3):195-9.

41. . Ranasinghe AW, Johnson NW, Scragg MA. Iron deficiency depresses cell proliferation in hamster cheek pouch epithelium. Cell Tissue Kinet. 1987 Jul;20(4):403-12.

42. . La Vecchia $G$, Tavani A. Fruit and vegetables and human cancer. Eur J Cancer Prev 1998; 7:3-8.

43. .Block G, Patterson B, Subar A.Fruit, vegetables, and cancer prevention: a review of the epidemiological evidence. Nutr Cancer. 1992;18(1):1-29 
44. . Potter JD, Steinmetz K. vegetables, Fruits and phyto

45. Winn DM. Diet and nutrition in the etiology of oral cancer.Am J Clin Nutr. 1995 Feb;61(2):437S-445S

46. McLaughlin JK, Gridley G, Block G, Winn DM, Preston-Martin S, Schoenberg JB, Greenberg RS, Stemhagen A, Austin DF, Ershow AG, et al.Dietary factors in oral and pharyngeal cancer.J Natl Cancer Inst. 1988 Oct 5;80(15):1237-43.

47. Woods KV, Shillitoe EJ, Spitz MR, Schantz SP, Adler-Storthz K. Analysis of human papillomavirus DNA in oral squamous cell carcinomas.J Oral Pathol Med. 1993 Mar;22(3):101-8

48. Mao EJ. Prevalence of human papillomavirus 16 and nucleolar organizer region counts in oral exfoliated cells from normal and malignant epithelia. Oral Surg Oral Med Oral Pathol Oral Radiol Endod. 1995 Sep;80(3):320-9

49. Yeudall WA. Human papillomaviruses and oral neoplasia. Eur J Cancer B Oral Oncol. 1992 Jul; 28B(1): 61-6

50. Kim MS, Shin KH, Baek JH, Cherrick HM, Park NH. HPV-16, tobacco-specific $\mathrm{N}$-nitrosamine, and $\mathrm{N}$-methyl-N'-nitro-N-nitrosoguanidine in oral carcinogenesis. Cancer Res. 1993 Oct 15; 53(20): 4811-6.

51. Shin KH, Tannyhill RJ, Liu X, Park NH. Oncogenic transformation of HPVimmortalized human oral keratinocytes is associated with the genetic instability of cells. Oncogene. 1996 Mar 7; 12(5): 1089-96.

52. International Union Against Cancer, www.UICC.org

53. Marques MM, Garcia FR, Garrido AM, et al. Prognostic factors for the oral cavity carcinoma. Rev Esp Cirug Oral Maxillfac 1994;16; 1-9. 
54. Funk GF, Karnell LH, Robinson RA, Zhen WK, Trask DK, Hoffman HT.. Presentation, treatment, and outcome of oral cavity cancer: a National Cancer Data Base report Head Neck. 2002 Feb;24(2):165-80.

55. Franco EL, Dib LL, Pinto DS, Lombardo V, Contesini H. Race and gender influences on the survival of patients with mouth cancer J Clin Epidemiol. 1993 Jan;46(1):37-46

56. Kaplan MH, Feinstein AR. The importance of classifying initial co-morbidity in evaluatin the outcome of diabetes mellitus. J Chronic Dis. 1974 Sep;27(7-8):387404

57. Charlson ME, Pompei P, Ales KL, MacKenzie CR.. A new method of classifying prognostic comorbidity in longitudinal studies: development and validation. $\mathrm{J}$ Chronic Dis 1987;40(5):373-83.

58. Havlik RJ, Yancik R, Long S, Ries L, Edwards B.The National Institute on Aging and the National Cancer Institute SEER collaborative study on comorbidity and early diagnosis of cancer in the elderly. Cancer. 1994 Oct 1;74(7 Suppl):2101-6.

59. Bang D, Piccirillo JF, Littenberg B, Johnston A. The Adult comorbidity Evaluation-27 (ACE-27) test: a new comorbidity index for patients with cancer. Presented at annual Meeting of the American Society of Clinical oncology, New Orleans, May 20, 2000

60. Borggreven PA, Kuik DJ, Langendijk JA, Doornaert P, de Bree R, Leemans CR.Severe comorbidity negatively influences prognosis in patients with oral and oropharyngeal cancer after surgical treatment with microvascular reconstruction. Oral Oncol. 2005 Apr;41(4):358-64 
61. Shah JP. Head and neck surgery, $2^{\text {nd }}$ ed. London: Mosby-Wolfe, 1996: 189-196

62. Magnano M, De Stefani A, Lerda W, Usai A, Ragona R, Bussi M, Cortesina G. Prognostic factors of cervical lymph node metastasis in head and neck squamous cell carcinoma. Tumori. 1997 Nov-Dec;83(6):922-6.

63. Magnano M, Bongioannini G, Lerda W, Canale G, Tondolo E, Bona M, Viora L, Gabini A, Gabriele P. Lymphnode metastasis in head and neck squamous cells carcinoma: multivariate analysis of prognostic variables. J Exp Clin Cancer Res. 1999 Mar; $18(1): 79-83$

64. Pernot M, Hoffstetter S, Peiffert D, Aletti P, Lapeyre M, Marchal C, Luporsi E, Bey P, Nancy VL. Role of interstitial brachytherapy in oral and oropharyngeal carcinoma: reflection of a series of 1344 patients treated at the time of initial presentation. Otolaryngol Head Neck Surg. 1996 Dec;115(6):519-26.

65. Jones AS. Prognosis in mouth cancer: tumor factors Eur J Cancer B Oral Oncol. 1994 Jan;30B(1):8-15.

66. Mamelle G, Pampurik J, Luboinski B, Lancar R, Lusinchi A, Bosq J. Lymph node prognostic factors in head and neck squamous cell carcinomas in patients with lymph node involvement. Am J Surg. 1994 Nov;168(5):494-8.

67. Olsen KD, Caruso M, Foote RL, Stanley RJ, Lewis JE, Buskirk SJ, Frassica DA, DeSanto LW, O'Fallon WM, Hoverman VR Primary head and neck cancer. Histopathologic predictors of recurrence after neck dissection. . Arch Otolaryngol Head Neck Surg. 1994 Dec;120(12):1370-4. 
68. Shah JP, Cendon RA, Farr HW, Strong EW. Carcinoma of the oral cavity. factors affecting treatment failure at the primary site and neck. Am J Surg. 1976 Oct;132(4):504-7.

69. Breslow A. Thickness, cross-sectional areas and depth of invasion in the prognosis of cutaneous melanoma. Ann Surg. 1970 Nov;172(5):902-8

70. Spiro RH, Huvos AG, Wong GY, Spiro JD, Gnecco CA, Strong EW. Predictive value of tumor thickness in squamous carcinoma confined to the tongue and floor of the mouth Am J Surg. 1986 Oct;152(4):345-50

71. Brown B, Barnes L, Mazariegos J, Taylor F, Johnson J, Wagner RL.. Prognostic factors in mobile tongue and floor of mouth carcinoma. Cancer. 1989 Sep $15 ; 64(6): 1195-202$

72. O'Brien CJ, Lauer CS, Fredricks S, Clifford AR, McNeil EB, Bagia JS, Koulmandas C.. Tumor thickness influences prognosis of T1 and T2 oral cavity cancer--but what thickness? Head Neck. 2003 Nov;25(11):937-45

73. . Rahima B, Shingaki S, Nagata M, Saito C.Prognostic significance of perineural invasion in oral and oropharyngeal carcinoma.Oral Surg Oral Med Oral Pathol Oral Radiol Endod. 2004 Apr;97(4):423-31.

74. Lydiatt DD, Robbins KT, Byers RM, Wolf PF. Treatment of stage I and II oral tongue cancer. Head Neck. 1993 Jul-Aug;15(4):308-12

75. Fagan JJ, Collins B, Barnes L, D'Amico F, Myers EN, Johnson JT.Perineural invasion in squamous cell carcinoma of the head and neck.Arch Otolaryngol Head Neck Surg. 1998 Jun;124(6):637-40. 
76. Soo KC, Carter RL, O'Brien CJ, Barr L, Bliss JM, Shaw HJ.. Prognostic implications of perineural spread in squamous carcinomas of the head and neck. Laryngoscope. 1986 Oct;96(10):1145-8.

77. Johnson JT, Myers EN, Bedetti CD, Barnes EL, Schramm VL Jr, Thearle PB.Cervical lymph node metastases. Incidence and implications of extracapsular carcinoma. Arch Otolaryngol. 1985 Aug;111(8):534-537.

78. Shah JP, Medina JE, Shaha AR, Schantz SP, Marti JR. Cervical lymph node metastasis. Curr Probl Surg. 1993 Mar;30(3):1-335

79. Myers JN, Greenberg JS, Mo V, Roberts D. Extracapsular spread. A significant predictor of treatment failure in patients with squamous cell carcinoma of the tongue. Cancer. 2001 Dec 15;92(12):3030-6

80. Kalnins IK, Leonard AG, Sako K, Razack MS, Shedd DP.. Correlation between prognosis and degree of lymph node involvement in carcinoma of the oral cavity Am J Surg. 1977 Oct;134(4):450-4

81. Johnson JT, Wagner RL, Myers EN.. A long-term assessment of adjuvant chemotherapy on outcome of patients with extracapsular spread of cervical metastases from squamous carcinoma of the head and neck. Cancer. 1996 Jan $1 ; 77(1): 181-5$

82. Loree TR, Strong EW. Significance of positive margins in oral cavity squamous carcinoma. .Am J Surg. 1990 Oct;160(4):410-4

83. Batsakis JG.Surgical excision margins: a pathologist's perspective. Adv Anat Pathol. 1999 May;6(3):140-8. 
84. Meier JD, Oliver DA, Varvares MA. Head Neck. 2005 Nov;27(11):952-8. Surgical margin determination in head and neck oncology: Current clinical practice. The results of an International American Head and Neck Society Member Survey.

85. Jacobs JR, Ahmad K, Casiano R, Schuller DE, Scott C, Laramore GE, al-Sarraf M.Implications of positive surgical margins. Laryngoscope. 1993 Jan;103(1 Pt 1):64-8.

86. McMahon J, O'Brien CJ, Pathak I, Hamill R, McNeil E, Hammersley N, Gardiner $\mathrm{S}$, Junor E..Influence of condition of surgical margins on local recurrence and disease-specific survival in oral and oropharyngeal cancer. Br J Oral Maxillofac Surg. 2003 Aug;41(4):224-31

87. Spiro RH, Guillamondegui O Jr, Paulino AF, Huvos AG.Pattern of invasion and margin assessment in patients with oral tongue cancer. Head Neck. 1999 Aug;21(5):408-13

88. Haddadin KJ, Soutar DS, Webster MH, Robertson AG, Oliver RJ, MacDonald DG.Natural history and patterns of recurrence of tongue tumours.Br J Plast Surg. 2000 Jun;53(4):279-85.

89. Yuen AP, Lam KY, Wei WI, Lam KY, Ho CM, Chow TL, Yuen WF. A comparison of the prognostic significance of tumor diameter, length, width, thickness, area, volume, and clinicopathological features of oral tongue carcinoma.Am J Surg. 2000 Aug;180(2):139-43 
90. Yuen PW, Lam KY, Chan AC, Wei WI, Lam LK.Clinicopathological analysis of local spread of carcinoma of the tongue.Am J Surg. 1998 Mar;175(3):242-4.

91. Beaumont DG, Hains JD. Change in surgical margins in vivo following resection and after fixation. Aust J OtoLaryngol 1992; 1: 51-2

92. Johnson RE, Sigman JD, Funk GF, Robinson RA, Hoffman HT.Quantification of surgical margin shrinkage in the oral cavity.Head Neck. 1997 Jul;19(4):281-6.

93. Krubhaar EB. Clio Med 19, Pathology. New York: PB Hoeber, Inc., 1937: 171

94. Ord RA, Aisner S. Accuracy of frozen sections in assessing margins in oral cancer resection. J Oral Maxillofac Surg. 1997 Jul;55(7):663-9

95. Zieske LA, Johnson JT, Myers EN, Thearle PB.Squamous cell carcinoma with positive margins. Surgery and postoperative irradiation.Arch Otolaryngol Head Neck Surg. 1986 Aug;112(8):863-6

96. Sutton DN, Brown JS, Rogers SN, Vaughan ED, Woolgar JA.The prognostic implications of the surgical margin in oral squamous cell carcinoma.Int $\mathbf{J}$ Oral Maxillofac Surg. 2003 Feb;32(1):30-4

97. Jones AS, Bin Hanafi Z, Nadapalan V, Roland NJ, Kinsella A, Helliwell TR.Do positive resection margins after ablative surgery for head and neck cancer adversely affect prognosis? A study of 352 patients with recurrent carcinoma following radiotherapy treated by salvage surgery. $\mathrm{Br}$ J Cancer. 1996 Jul;74(1):128-32

98. Amdur RJ, Parsons JT, Mendenhall WM, Million RR, Stringer SP, Cassisi NJ.Postoperative irradiation for squamous cell carcinoma of the head and neck: an 
analysis of treatment results and complications.Int J Radiat Oncol Biol Phys. 1989 Jan;16(1):25-36

99. Zelefsky MJ, Harrison LB, Fass DE, Armstrong JG, Shah JP, Strong EW.Postoperative radiation therapy for squamous cell carcinomas of the oral cavity and oropharynx: impact of therapy on patients with positive surgical margins. Int J Radiat Oncol Biol Phys. 1993 Jan;25(1):17-21. Erratum in: Int J Radiat Oncol Biol Phys 1993 Apr 2;25(5):935., Int J Radiat Oncol Biol Phys. $1993 ; 25: 17-21$

100. Beitler JJ, Smith RV, Silver CE, Quish A, Deore SM, Mullokandov E, Fontenla DP, Wadler S, Hayes MK, Vikram B.Close or positive margins after surgical resection for the head and neck cancer patient: the addition of brachytherapy improves local control.Int J Radiat Oncol Biol Phys. 1998 Jan $15 ; 40(2): 313-7$

101. Rodrigo JP, Ferlito A, Suarez C, Shaha AR, Silver CE, Devaney KO, Bradley PJ, Bocker JM, McLaren KM, Grenman R, Rinaldo A.New molecular diagnostic methods in head and neck cancer.Head Neck. 2005 Nov;27(11):995100

102. Brennan JA, Mao L, Hruban RH, Boyle JO, Eby YJ, Koch WM, Goodman SN, Sidransky D. Molecular assessment of histopathological staging in squamous-cell carcinoma of the head and neck.N Engl J Med. 1995 Feb $16 ; 332(7): 429-35$ 
103. Ogden GR, Chisholm DM, Morris AM, Stevenson JH. Overexpression of p53 in normal oral mucosa of oral cancer patients does not necessarily predict further malignant disease.J Pathol. 1997 Jun;182(2):180-4

104. Nathan CA, Amirghahri N, Rice C, Abreo FW, Shi R, Stucker FJ.Molecular analysis of surgical margins in head and neck squamous cell carcinoma patients.Laryngoscope. 2002 Dec;112(12):2129-40

105. Franklin S, Pho T, Abreo FW, Nassar R, De Benedetti A, Stucker FJ, Nathan CA. Detection of the proto-oncogene eIF4E in larynx and hypopharynx cancers.Arch Otolaryngol Head Neck Surg. 1999 Feb;125(2):177-82

106. Goldenberg D, Harden S, Masayesva BG, Ha P, Benoit N, Westra WH, Koch WM, Sidransky D, Califano JA.Arch Otolaryngol. Intraoperative molecular margin analysis in head and neck cancer. Head Neck Surg. 2004 Jan;130(1):39-44

107. Kaplan ER, Meier P. Non-parametric estimation from incomplete observations. J Am Stat Assoc 1958;53:457-481.

108. Cox DR. Regression models and life tables. J R Stat Soc 1972;34:187-189.

109. Kaufman Z, Lew S, Griffel B, Dinbar A.Frozen-section diagnosis in surgical pathology. A prospective analysis of 526 frozen sections. Cancer. 1986 Jan $15 ; 57(2): 377-9$

110. Rogers C, Klatt EC, Chandrasoma P. Accuracy of frozen-section diagnosis in a teaching hospital.Arch Pathol Lab Med. 1987 Jun;111(6):514-, 111. Howanitz PJ, Hoffman GG, Zarbo RJ. The accuracy of frozen-section diagnoses in 34 hospitals.Arch Pathol Lab Med. 1990 Apr;114(4):355-9 
112. Ribeiro NF, Godden DR, Wilson GE, Butterworth DM, Woodwards RT.Do frozen sections help achieve adequate surgical margins in the resection of oral carcinoma? Int J Oral Maxillofac Surg. 2003 Apr;32(2):152-8

113. Suen JY, Newman RK, Hannahs K, Fisher J. Evaluation of the effectiveness of postoperative radiation therapy for the control of local disease.Am J Surg. 1980 Oct;140(4):577-9.,

114. Sadeghi A, Kuisk H, Tran LM, Mackintosh R, Mclaren JR, Parker RG. The role of radiation therapy in squamous cell carcinoma of the upper aerodigestive tract with positive surgical margins.Am J Clin Oncol. 1986 $\operatorname{Dec} ; 9(6): 500-3$

115. Vikram B, Strong EW, Shah JP, Spiro R. Failure at the primary site following multimodality treatment in advanced head and neck cancer.Head Neck Surg. 1984 Jan-Feb;6(3):720-3 et al

116. Brennan JA, Mao L, Hruban RH, Boyle JO, Eby YJ, Koch WM, Goodman SN, Sidransky D. Molecular assessment of histopathological staging in squamous-cell carcinoma of the head and neck.N Engl J Med. 1995 Feb $16 ; 332(7): 429-35$

117. Ogden GR, Chisholm DM, Morris AM, Stevenson JH. Overexpression of p53 in normal oral mucosa of oral cancer patients does not necessarily predict further malignant disease.J Pathol. 1997 Jun;182(2):180-4 
118. Franklin S, Pho T, Abreo FW, Nassar R, De Benedetti A, Stucker FJ, Nathan CA. Detection of the proto-oncogene eIF4E in larynx and hypopharynx cancers.Arch Otolaryngol Head Neck Surg. 1999 Feb;125(2):177-82 